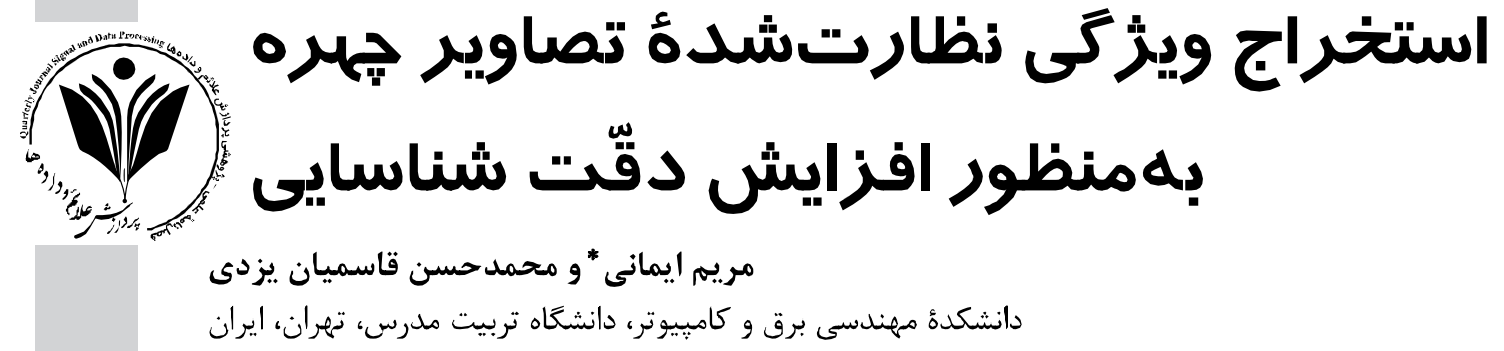

?

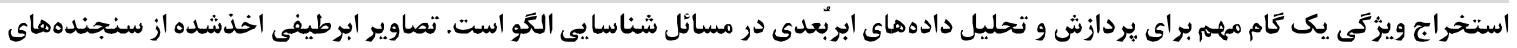

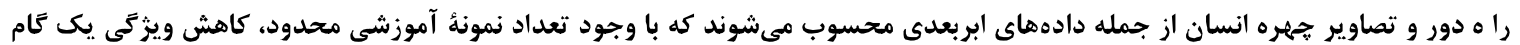

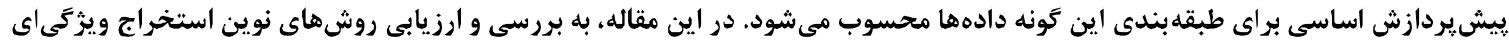

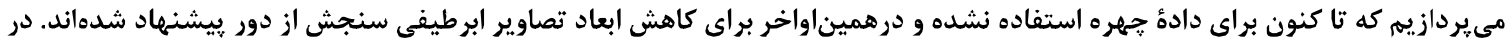

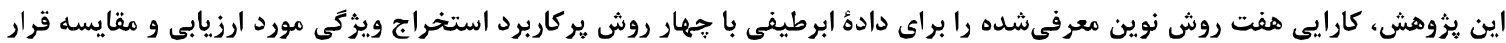

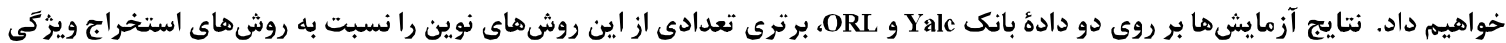
M و MMDDA ،WFE LDDA

وازَّان كليدى: ابرطيفى، استخراج ويرَّى، شناسايى جهره، طبقهبندى.

\title{
Supervised Feature Extraction of Face Images for Improvement of Recognition Accuracy
}

\author{
Maryam Imani* \& Hassan Ghassemian \\ Faculty of Electrical and Computer Engineering, Tarbiat Modares University, Tehran, Iran
}

\begin{abstract}
Dimensionality reduction methods transform or select a low dimensional feature space to efficiently represent the original high dimensional feature space of data. Feature reduction techniques are an important step in many pattern recognition problems in different fields especially in analyzing of high dimensional data. Hyperspectral images are acquired by remote sensors and human face images are one of the high dimensional data types. Because of limitation in the number of training samples, feature reduction is the important preprocessing step for classification of these types of data. Face recognition is one of the main interesting studies in human computer interaction applications. Face is among the most significant biometric characteristics which are used for identification of individuals. Before face recognition, feature reduction is an important processing step. In this paper, we apply the new feature extraction methods, which have been firstly_proposed for feature reduction of hyperspectral imagery remote sensing, on the face databases for the first time. In this research, we compare the performance of seven new feature extraction methods with four state-of-the-art feature extraction methods. The proposed methods are Nonparametric Supervised Feature Extraction (NSFE), Clustering Based Feature Extraction (CBFE), Feature Extraction Using Attraction Points (FEUAP), Cluster Space Linear Discriminant Analysis (CSLDA), Feature Space Discriminant Analysis (FSDA), Feature Extraction using Weighted Training samples (FEWT), and Discriminant Analysis- Principal Component 1 (DA-PC1). The experimental results on two face databases, Yale and ORL, show the better
\end{abstract}

* Corresponding author ن 
performance of some new feature extraction methods, from the recognition accuracy point of view compared to methods such as linear discriminant analysis (LDA), non-parametric weighted feature extraction (NWFE), median-mean line discriminant analysis (MMLDA), and supervised locality preserving projection (LPP).

Keywords: Face recognition, Feature extraction, Classification, Hyperspectral.

به دو شيوه نظارتشده و بدون نظارت قابل بيادهسازى است

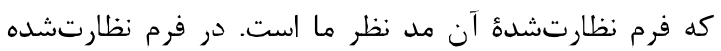

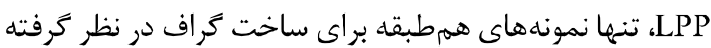

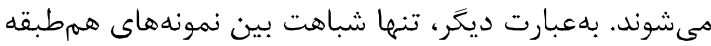

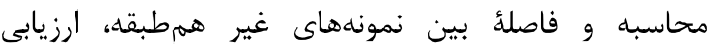

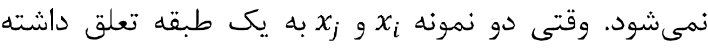

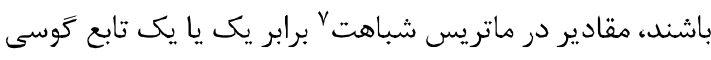
م در نظر كرفته مىشود و در غير اين صورت، $\exp \left(\frac{-\left\|x_{i}-x_{j}\right\|^{2}}{t}\right)$ مقدارى برابر صفر بد آن نسبت داده مىشود.

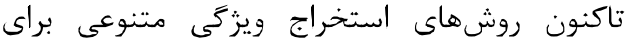

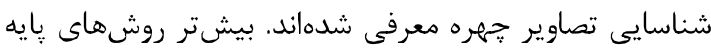

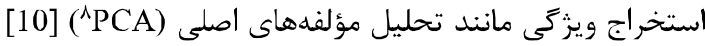

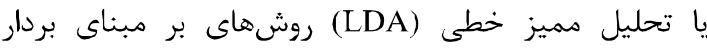

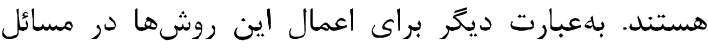

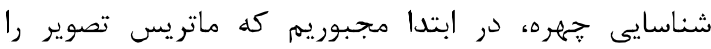
سطربهسطر يا ستونبهستون به يك بردار تصوير تبديل كرده و سيس تبديل استخراج ويزّى مورد نظر را بر روى بردار

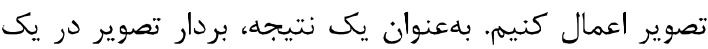
فضاى بعد بالا (بهطور كلى فراتر از تعداد نمونهها) قرار

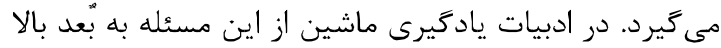

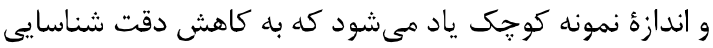

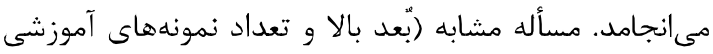

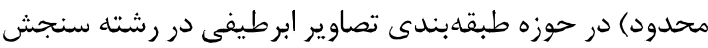

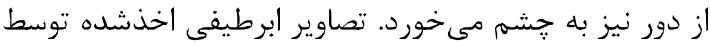

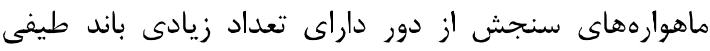

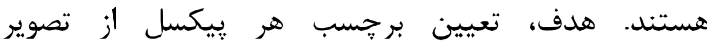
(طبقدبندى آن) است. هر ييكسل داراى بُعد بالا، به عبارتين

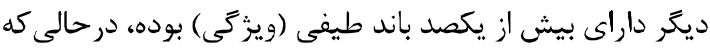

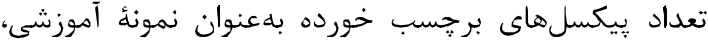

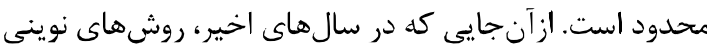

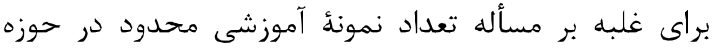
تصاوير ابرطيفى سنجش از دور معرفى شده است، در اين مقاله

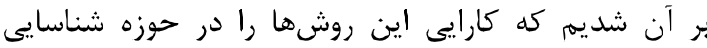
تصاوير جهره نيز مورد آزمايش قرار دهيه.

${ }^{7}$ Similarity Matrix

${ }^{8}$ Principal Component Analysis (PCA)

\section{- - مقدمه} استخراج ويزگى و طبقهبندى دادههاى ابربعدى از مسائل مهرم

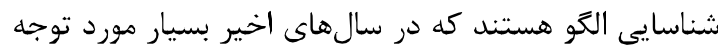
قرار كرفتهاند [5-1]. از آنجايى كه بيشتر روشهاى استخراج ويثزَى بر روى بردار عمل مى كنند، براى استفاده از اين

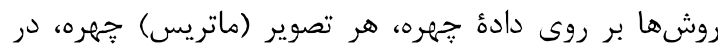
ابتدا، سطربهسطر يا ستونبلهتون تبديل به يك بردار مى شودود

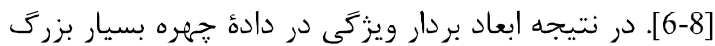

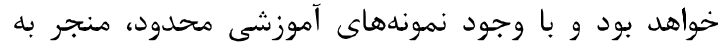
بديده هيوز [9] خواهد شد.

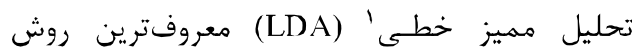
استخراج ويزگى است كل از بيشينهكرن زيراكندكىهاى بين طبقهاى و كمينه كردن يراكندگى هاى درون طبقهاى جهت

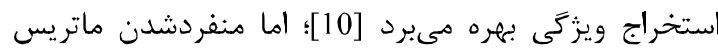
يراكندگى درون طبقهاى با استفاده از مجموعه نمونه آموزشى في مانى

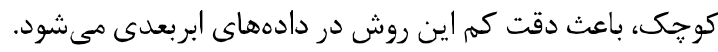

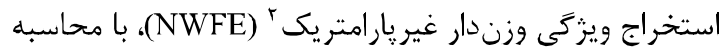

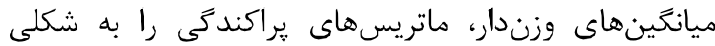

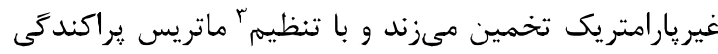
درونطبقهاى با مشكل نمونههاى آموزشى محدود مقابله مى كند [111]. تحليل مميز خطى ميانه-ميانكين ' (MMLDA) روش استخراج ويزگى ديخرى است كه در سالهاى اخير معرفى شده و از خط ميانه-ميانخين در تخمين ماتريسهري دهاى

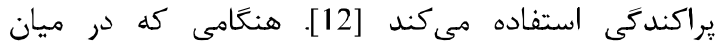
نمونهاي آموزشى، نمونهُ يرتى وجود داشته باشد، ميانكين معيار قابل اطمينانى نخواهد بود و استفاده از هر دو معيار ميانه و ميانظين نتايج يايورترى با استفاده از MMLDA فراهم مىآورد. تصوير حفظ محليته ميات (LPP) نيز يك روش استخراج ويزگى است كه از اطلاعات جدايىيذيرى طبقهها بهرهاى

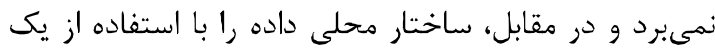

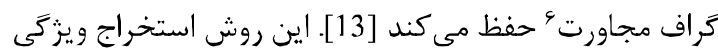

\footnotetext{
${ }^{1}$ Lincar Discriminant Analysis

${ }^{2}$ Nonparametric Weighted Feature Extraction

${ }^{3}$ Regularization

${ }^{4}$ Median-Mean and Feature Line Embedding

${ }^{5}$ Locality Preserving Projection

${ }^{6}$ Adjacency Graph
} 
هندين خوشه تعلق داشته باشند. به ميزان احتمال اختصاص

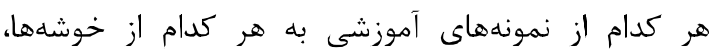

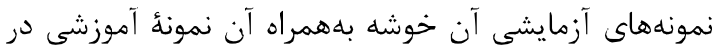

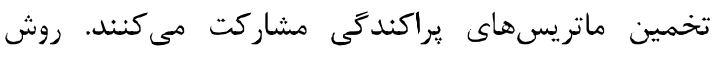

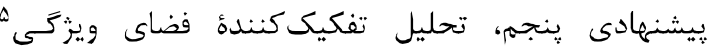

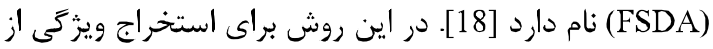

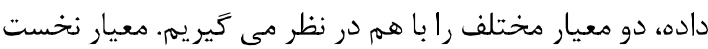
اين است كه ويزكى هاى انتخابشده تا حد امكان از هم متمايز

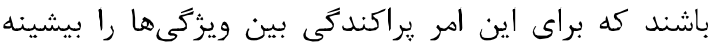

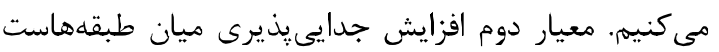

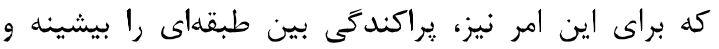

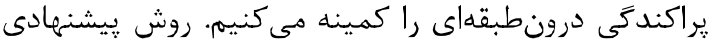

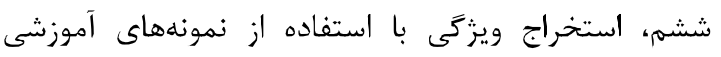

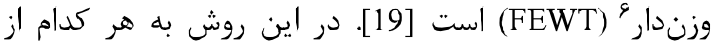

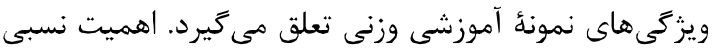

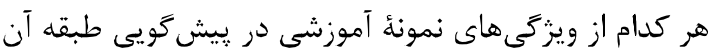

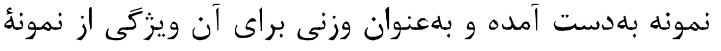

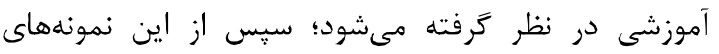

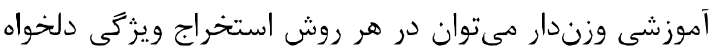
استفاده كرد. روش يِيشنهادى هفتمه، تحليل مميز - مؤلفه

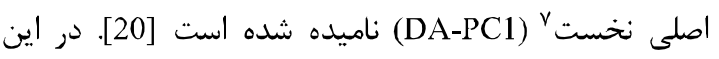
روش، ماتريسهاى يراكندكى درونطبقهاى و بينطبقهاى به نايه

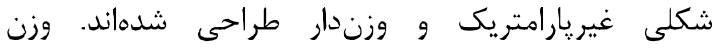
اختصاصيافته به هر جفت از نمونههاى آموزشى كه در در تخمين

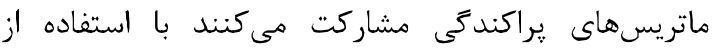

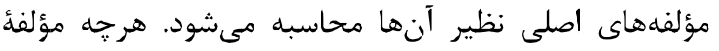

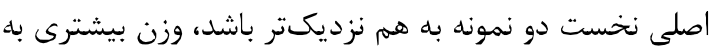

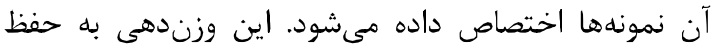
ساختار اصلى داده (در كنار افزايش جدايى يذيرى طبقهها) كمك خواهد كرد. - ماهن

روشهاى شناسايى خهره به دو دسته كلى روشهاى

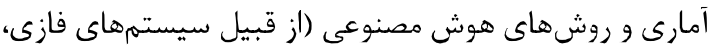
شبكههاى عصبى و الكوريتمهاى تكاملى) تقسيم مى شى آشوند.

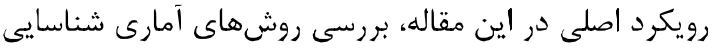

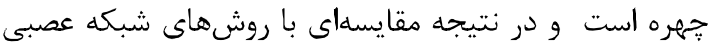

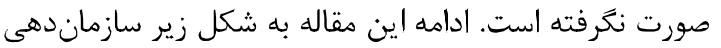

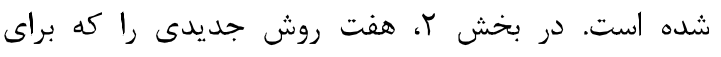
استخراج ويزّكى از داده ابرطيفى معرفى شدهاند، بهاختصار

${ }^{5}$ Feature Space Discriminant Analysis

${ }^{6}$ Feature Extraction using Weighted Training samples

${ }^{7}$ Discriminant $\Lambda$ nalysis- Principal Component 1
روش استخراج ويزگى پِيشنهادى نخست، استخراج

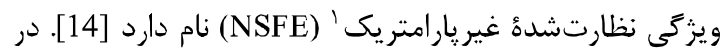
اين روش ماتريسهاى براكندكى درون طبقهاى و غيرطبقائ

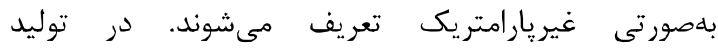
ماتر يسهاى ير اكندكى، تنها نياز به محاسبه ميانگين كلى بوده

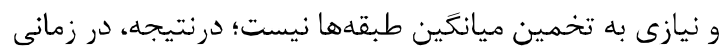

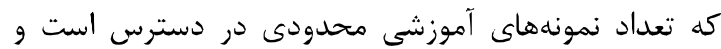

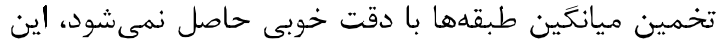
روش كار ايى خوبى خواهد داشت. بهعلاوه، بددليل استفاده از خود نمونههاى آموزشى به جاى ميانغَين طبقهها در تخمين

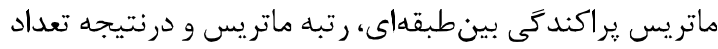

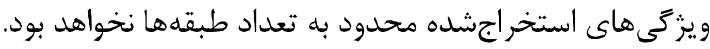
روش ويشنهادى دوم، استخراج ويزّى بر مبناى خوشهبندى

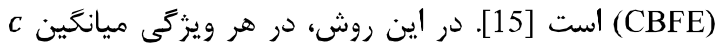

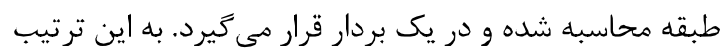

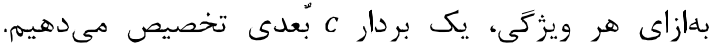

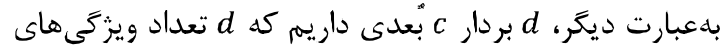

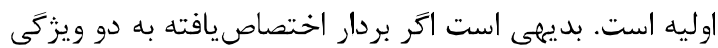
مشابه باشد، اين دو ويزگكى داراى توانايى يكسانى در تميز

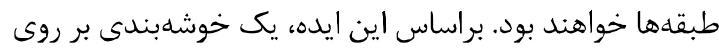
اين بردارها انجام مىدهيم. روش ويشنهاديادى سوم استخراج

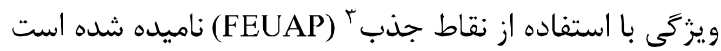

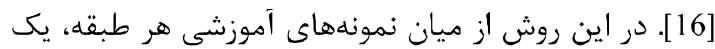

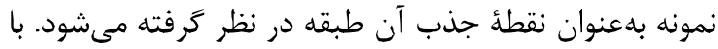

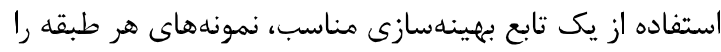

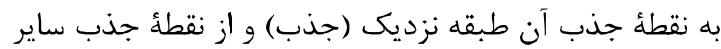
طبقهها دور مي كنيم (دفع). به اين ترتيب، با انتخاب مناسب

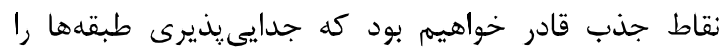
افزايش دهيم. روش بيشنهادى جههارم، تحليل مميز خطى جانى

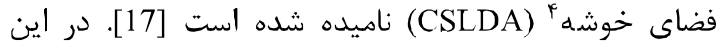

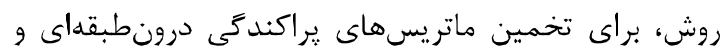

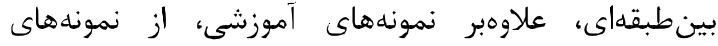

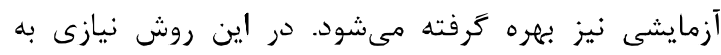

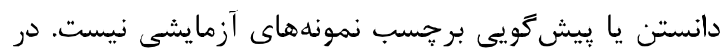
اين روش يك خوشهبندى بر روى مجموعهدادة آزمايشى انجام

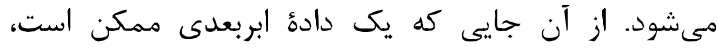

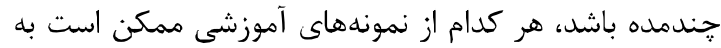

\footnotetext{
${ }^{1}$ Nonparametric Supervised Feature Extraction

${ }^{2}$ Clustering Based Feature Extraction

${ }^{3}$ Feature Extraction Using Attraction Points

${ }^{4}$ Cluster Space Linear Discriminant Analysis
} 
نمونه آموزشى محدود، كارايى خوبى دارد. در اين روش، ابتدا

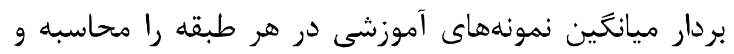

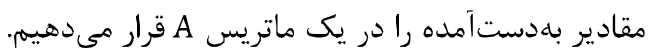
$\mathbf{A}=\left[\begin{array}{cccc}m_{11} & m_{12} & \cdots & m_{1 c} \\ m_{21} & m_{22} & \cdots & m_{2 c} \\ \vdots & \vdots & \vdots & \vdots \\ m_{d 1} & m_{d 2} & \cdots & m_{d c}\end{array}\right]$

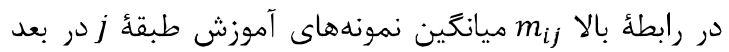

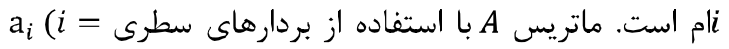
1, 2, ,.., d) مى تواند بهشكل زير بازنويسى شود:

$\mathrm{A}=\left[\begin{array}{c}\mathrm{a}_{1} \\ \mathrm{a}_{2} \\ \vdots \\ \mathrm{a}_{d}\end{array}\right]$

هر بردار

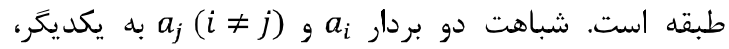

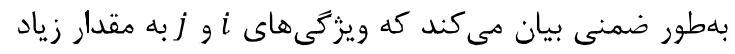

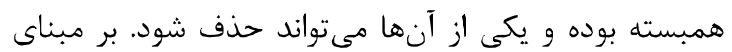

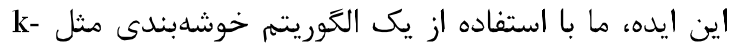
بردارهاى means

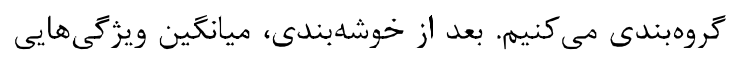
كه بردار a نظير آنها در يك خوشه قرار ترفتهاند، بهعنوان

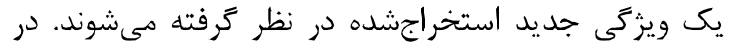

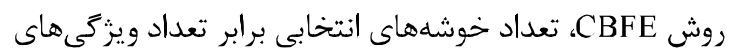

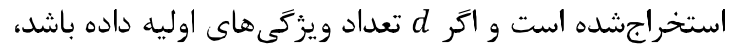
داريم: Sd 1 1. روش CBFE بر خلاف روشهايى مانند

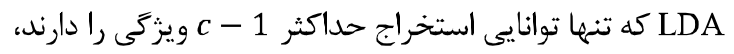
قادر به استخراج هر تعداد ويثزى دلخى دلخواه است.

\section{r-r- استخراج ويثزى با استفاده از نقاط جذب}

\section{(FEUAP)}

$\left\{x_{i}\right\}_{i=1}^{N}, x_{i} \in$ تصوير ابرطيفى را در فضاى ويزگكى با بعد بالا

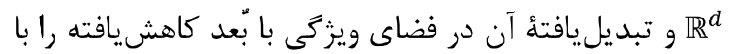
演 $\left\{y_{i}\right\}_{i=1}^{N}, y_{i} \in \mathbb{R}^{m}$

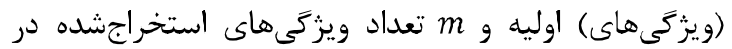

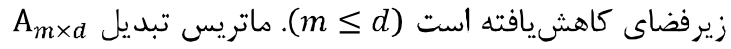

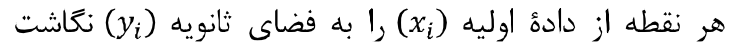
مى كند: است؛ بهكونهاى كه داده در فضاى كاهشيافته نيز براى طبقهبندى مناسب باشد. درنتيجه، بايد تبديل را بهَّونهاى انجام دهيم كه در فضاى تبديليافته (كاهشيافته) تمايز بين

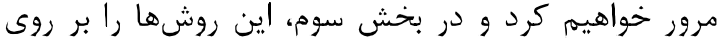

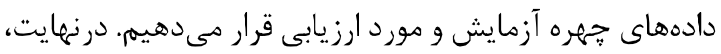
جمعبندى مقاله در بخش جهارم بيان شده است.

r- روشهاى نوين استخراج ويزَى ائى

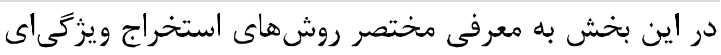

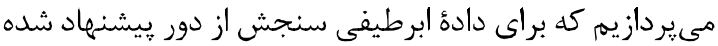

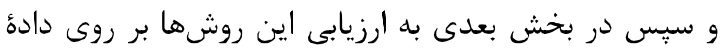
جهره خواهيم برداخت.

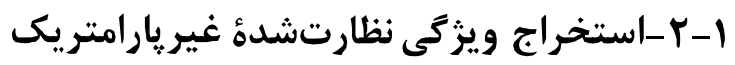
(NSFE)

در اين روش، كه سعى در فشردهسازى نمونههاى هممطبقه و

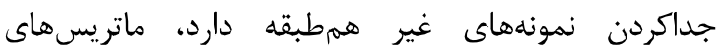

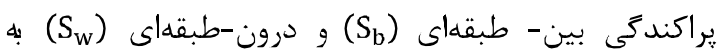
شكل وزندار و غيريارامتريك زير تعريف شدهاند:

$\mathrm{S}_{\mathrm{b}}=\sum_{\mathrm{k}=1}^{\mathrm{c}} \sum_{\mathrm{i}=1}^{\mathrm{n}_{\mathrm{k}}} \mathrm{n}_{\mathrm{k}} \mathrm{d}\left(\mathrm{x}_{\mathrm{i}, \mathrm{k}}, \mathrm{m}\right)\left(\mathrm{x}_{\mathrm{i}, \mathrm{k}}-\mathrm{m}\right)\left(\mathrm{x}_{\mathrm{i}, \mathrm{k}}-\mathrm{m}\right)^{\mathrm{T}}$

$\mathrm{S}_{\mathrm{w}}=\sum_{\mathrm{k}=1}^{\mathrm{c}} \sum_{\mathrm{j}=1}^{\mathrm{n}_{\mathrm{k}}} \sum_{\mathrm{i}=1}^{\mathrm{n}_{\mathrm{k}}} \mathrm{d}\left(\mathrm{x}_{\mathrm{i}, \mathrm{k}}, \mathrm{x}_{\mathrm{j}, \mathrm{k}}\right)\left(\mathrm{x}_{\mathrm{i}, \mathrm{k}}-\mathrm{x}_{\mathrm{j}, \mathrm{k}}\right)\left(\mathrm{x}_{\mathrm{i}, \mathrm{k}}-\mathrm{x}_{\mathrm{j}, \mathrm{k}}\right)^{\mathrm{T}}(\mathrm{T})$

كه در روابط بالا

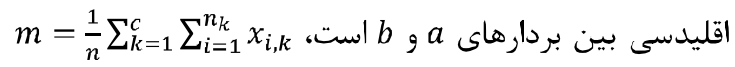

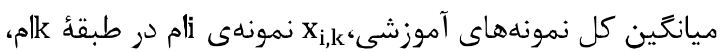

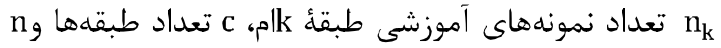

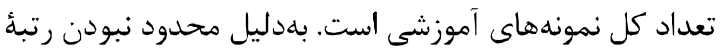
ماتريس تراكندكى بينطبقهاى، تعداد ويزگكى هاى استخراج

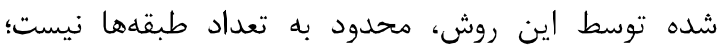

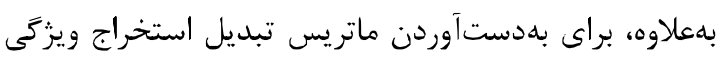

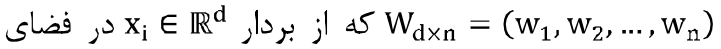
اوليه با بعد بالا، داده را به

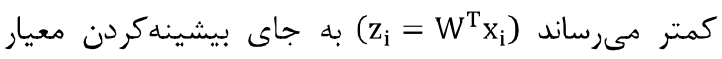
tr $\left.1 S_{w}{ }^{-1} S_{b}\right)$ شده است؛ درنتيجه، بهدليل نياز نداشتن به محاسبة معكوس

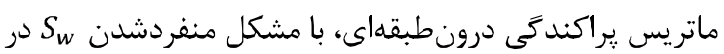

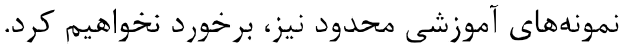

\section{r-r- استخراج ويثزَى بر مبناى خوشهبندى}

(CBFE)

روش استخراج ويزگى نظارتشده بر مبناى خوشهبندى تنها از آماركان مرتبه نخست (بردار ميانغين) (CBFE)

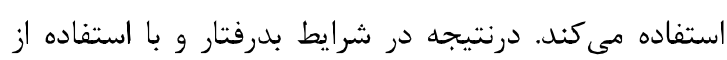


$\mathcal{F}\left(\boldsymbol{x}_{i c}\right)=\sum_{j=1}^{n_{t c}} e^{-\left\|x_{i c}-\boldsymbol{x}_{j c}\right\|^{2}}$

سبس، براى بهدستآوردن نقطؤ جذب طبقة c الم مسأله بهينهسازى زير را حل مى كنيم:

$s=\arg \max _{i=1, \ldots, n_{t c}} \mathcal{F}\left(\boldsymbol{x}_{i c}\right)$

در نتيجه، نمونهُ كام از طبقة cام بهعنوان نقطة جذب طبقة انتخاب مىشود، بهعبارت ديخر خواهيم داشت: براى مشخصكردن تابع تبديل مناسب براى توليد فضاى

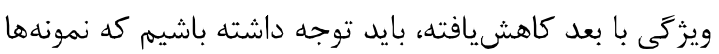
در فضاى كاهشيافته، بايد به گونهاى باشند كة:

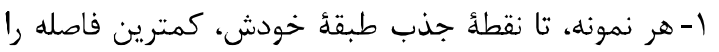
داشته باشد (جذب).

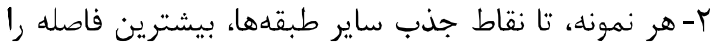
داشته باشد (دفع).

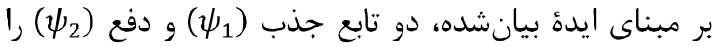

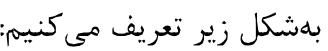

$\psi_{1}=\sum_{c=1}^{n_{c}} \sum_{i=1}^{n_{t c}}\left\|\boldsymbol{y}_{i c}-\boldsymbol{y}^{a c}\right\|^{2}$

$\psi_{2}=-\sum_{c=1}^{n_{c}} \sum_{i=1}^{n_{t c}} \sum_{\substack{k=1 \\ k \neq c}}^{n_{c}}\left\|\boldsymbol{y}_{i c}-\boldsymbol{y}^{a k}\right\|^{2}$

的 $y^{a c}=\mathrm{A} x^{a c}$ است. هم: קنين داريم: ماتريس تبديل A، بايد مسأله بهينهسازى را حل حل كنيم:

$\min _{\mathbf{A}}\left(\psi=\psi_{1}+\psi_{2}\right)$

تابع భ مى تواند بهشكل ديكَرى نيز نوشته شود:

$\psi=\sum_{j=1}^{n} \sum_{i=1}^{n} w_{i j}\left\|\boldsymbol{y}_{i}-\boldsymbol{y}_{j}\right\|^{2}$

$w_{i j}= \begin{cases}1 & \text { if } C 1 \\ -1 & \text { if } C 2 \\ 0 & \text { if } C 3\end{cases}$

شروط C1، C2 و C3 به شرح زير هستند: C1 حذب

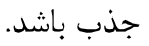

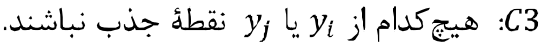

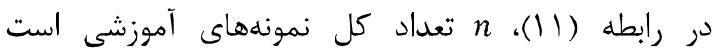
.

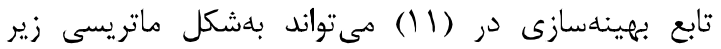
$\psi=2 \operatorname{tr}\left(\mathrm{YGY}^{\mathrm{T}}\right)$

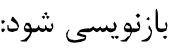

طبقهها افزايش يافته و در فضاى ويزگى جديد، طبقهها قابل جداسازى از هم باشند. روش ييشنهادى بر اساس ايدة زير

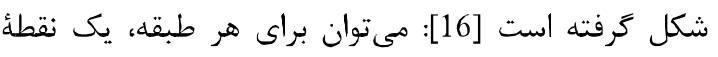
جذب ( مرجع) در نظر كرفت؛ بهَّونهاى كه نقاط جذب طرئ طبقهاى مختلف در فواصل دور از هم قرار كرفته باشند؛ سيس بايد تبديلى انجام دهيم كه نقاط آموزشى هر طبقه به به

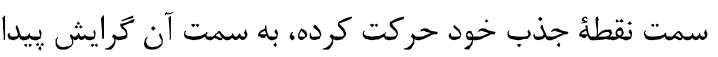
كنند و در اطراف آن جمع شوند. به اين ترتيب تمايز بين طبقهها در فضاى جديد رخ مى دهد (به شكل (1) توجه كنيد).

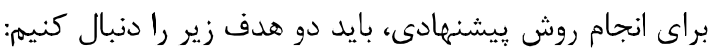
1- تعيين نقاط جذب هر طبقه

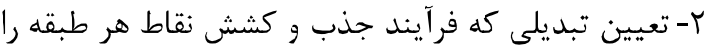
به سمت نقطهُ جذب متناظر آن طبقه، انجام دهدي

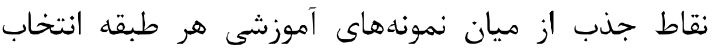
مىشوند. ما در اين قسمت دو روش براى تعيين نقاط جذب

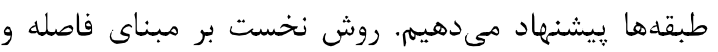

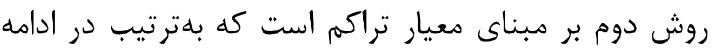

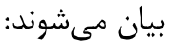
تعيين نقاط جذب با /ستفاده/ز معيار فاصله: در اين روش،

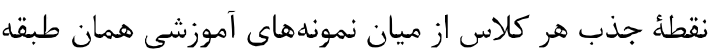

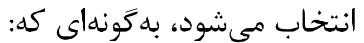

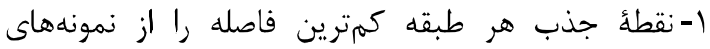

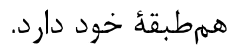
r- نقطأ جذب هر طبقه، بيشترين درد فاصله را از نمونههاى غير همبطبقه خود دارد.

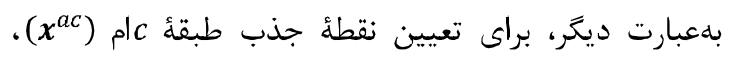
مسألة بهينهسازى زير بايد حل شود: $s=\arg \min _{i=1, \ldots, n n_{t c}}\left(\sum_{j=1}^{n_{t c}}\left\|\boldsymbol{x}_{i c}-x_{j c}\right\|^{2}-\sum_{\substack{k=1 \\ k \neq c}}^{n_{c}} \sum_{j=1}^{n_{t c}}\left\|\boldsymbol{x}_{i c}-x_{j k}\right\|^{2}\right)(\Delta)$ كه در نتيجه داريم: از طبقة cام،

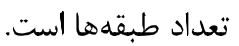
تعبين نقاط جذب با /ستفاده/ز معيار تراكمر: در اين روش،

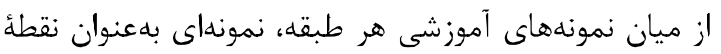
جذب انتخاب مىشود كه تعداد بيشترى از نمونههاى آن طبقه آنه

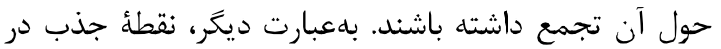

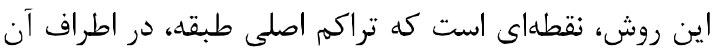

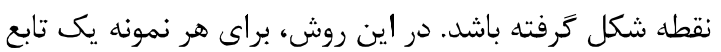
تراكم بهشكل زير تعريف مى كنيه: 
ماتريس تبديل خطى بهينه A از حل مسأله بهينهسازى مقدار

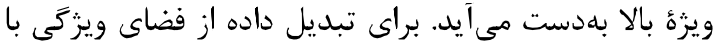

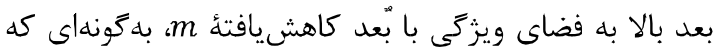

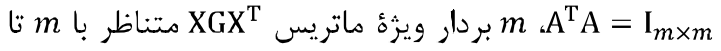

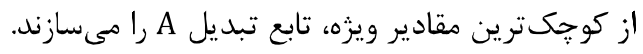

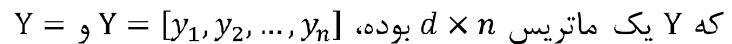
$\mathrm{G}=\mathrm{D}-\mathrm{W}$. AX, $\left(\mathrm{X}=\left[x_{1}, x_{2}, \ldots, x_{n}\right]\right)$ كه (بودها W يك ماتريس قطرى است و D

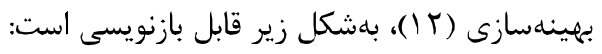
$\min _{\mathrm{A}} \psi=2 \operatorname{tr}\left(\mathrm{AXGX}^{\mathrm{T}} \mathrm{A}^{\mathrm{T}}\right)$

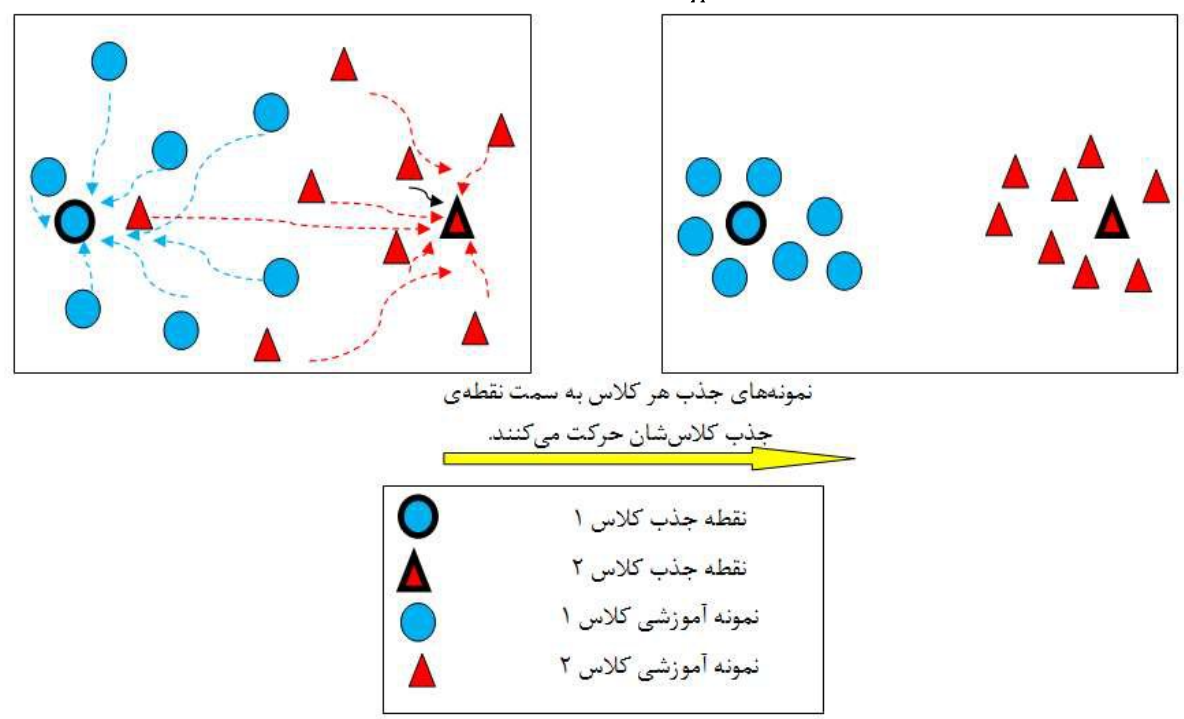

(شكل -1): حركت به سمت نقاط جذب در يك فضاى ويثَىى دو بعدى براى يك داده دو كلاسه

(Figure-1): moving toward attraction points in a two-dimensional feature space for a two-class dataset.

$\boldsymbol{M}=\left(\frac{1}{n_{c}}\right) \sum_{c=1}^{n_{c}} \boldsymbol{m}_{c}+\left(\frac{1}{K}\right) \sum_{k=1}^{K} \boldsymbol{\mu}_{k}$

در روابط بالا،

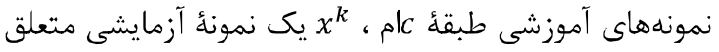

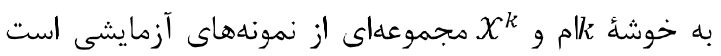
كه به خوشأ k|م تعلق دارند. K تعداد خوشهها و

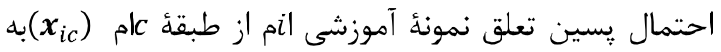
خوشأ k ام است. تركيبى كل است. همرجنين،

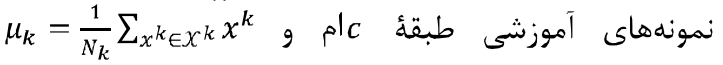

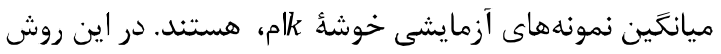

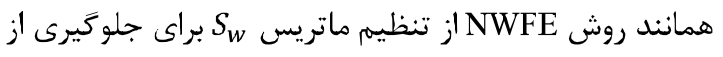

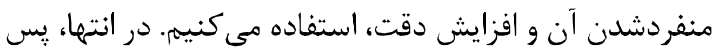

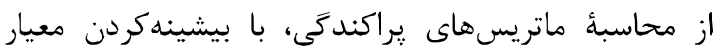
خو $\operatorname{tr}\left(S_{w}{ }^{-1} S_{b}\right)$

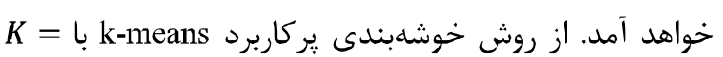
n بلمنظور خوشهبندى در [17] استفاده شده و رو تعداد خوشهها برابر تعداد طبقهها (K) است. يك ايراد روش CSLDA اين است كه رتبئ ماتريس تعاد
تحليل مميز خطى فضاى خوشه (CSLDA)

روش استخراج ويزگى CSLDA بدون نياز به تعيين برجسب

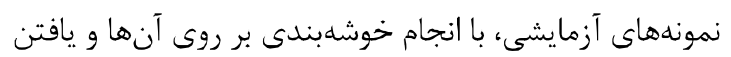

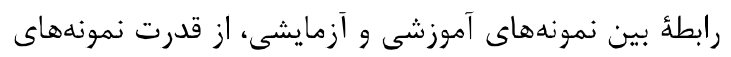

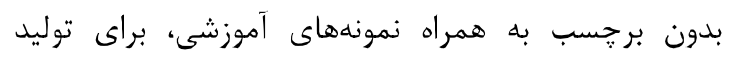

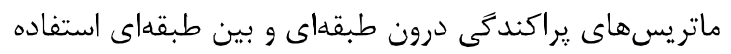

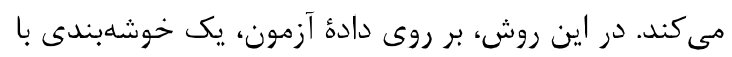

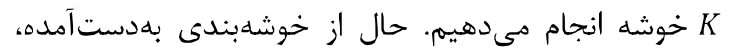

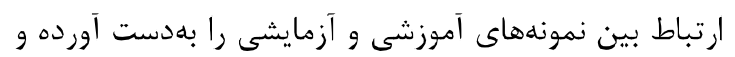

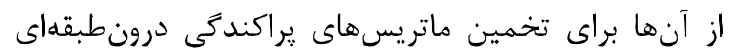
و بين طبقهاى (S $)$ (استفاده مى كنيم:

$\mathrm{S}_{w}=\sum_{c=1}^{n_{c}} \sum_{i=1}^{n_{t c}}\left[\left(x_{i c}-m_{c}\right)\left(x_{i c}-m_{c}\right)^{T}+\right.$

$\left.\sum_{k=1}^{K} \sum_{x^{k} \in X^{k}} p\left(k \mid x_{i c}\right)\left(x^{k}-\mu_{k}\right)\left(x^{k}-\mu_{k}\right)^{T}\right]$

$\mathrm{S}_{b}=\sum_{c=1}^{n_{c}} n_{t c}\left(M_{c}-M\right)\left(M_{c}-M\right)^{T}$

$\boldsymbol{M}_{c}=\boldsymbol{m}_{c}+\left(\frac{1}{n_{t c}}\right) \sum_{i=1}^{n_{t c}} \sum_{k=1}^{K} p\left(k \mid \boldsymbol{x}_{i c}\right) \boldsymbol{\mu}_{k}$ 
در روش LPP نظارتشده از نمونهاى آموزشى وزندار

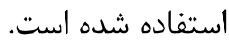

فرض كنيد $X_{n \times d}=\left[x_{1}, x_{2}, \ldots, x_{n}\right]^{T}$

نمونههاى آموزشى باشد كه نمونههاى آموزشى، ${ }$ تعداد طبقها و d تعداد ويزُكى ها (باندهاى طيفى) است.

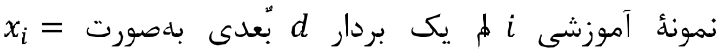

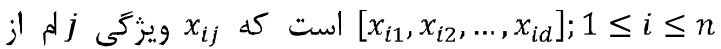
نمونه أام است. فرض كنيد باشد؛ ماتريس L حاوى مقادير صفر و يك است. اتر نمونهٔ أم متعلق به طبقة k باشد، در سطر أام تنها ستون kام مقدار يكى و ساير ستونها مقدار صفر دارند. با توجه به اهميت نسبى هر

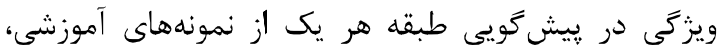

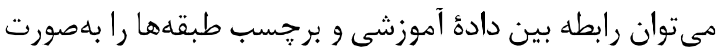

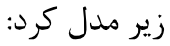

$L_{n \times c}=X_{n \times d} W_{d \times c}+1_{n} b^{T}$

كه n1 يك بردار ثابت 1 × 1 يُّدى است كه همأ المانهاى آن يك هستند و

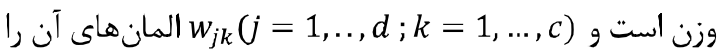
تشكيل مىدهند.

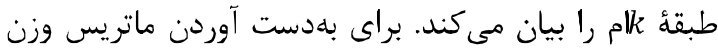

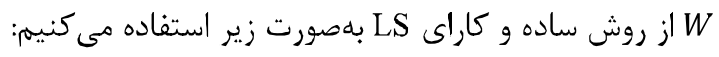
$\min _{W, b} \psi(W, b)=\left\|X W+1_{n} b^{T}-L\right\|_{F}^{2}+\gamma\|W\|_{F}^{2}$

كه $\left.\right|_{F}|| \mid$ بيان بلمنظور تنظيم استفاده شده و 0 > $>$ يك يارامتر مصالحه است. ماتريس W و بردار bا بهآسانى بر مبناى تئورى ماتريس

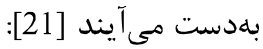

$W=\left(X^{T} H X+\gamma I_{d}\right)^{-1} X^{T} H L$

$b=\frac{L^{T} 1_{n}-W^{T} X^{T} 1_{n}}{n}$

كه در رابطة بالا:

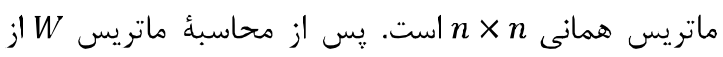

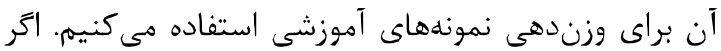

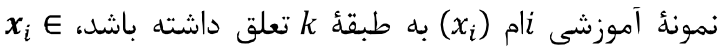

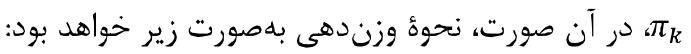
$z_{i j}=x_{i j} w_{j k} ; 1 \leq j \leq d$

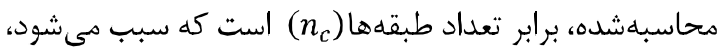

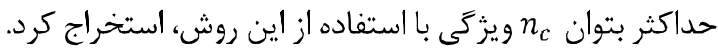

ه-r- تحليل تفكيك كنندهُ فضاى ويزگى (FSDA)

در روش تحليل تفكيك كنندة فضاى ويزّكى FSDA براى

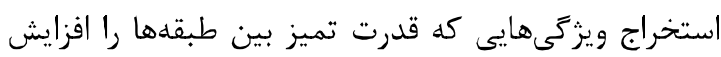

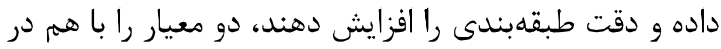
نظر مى كيريه. ويزَّىهاى استخراجشده بايد بلهَّونهاي باشند

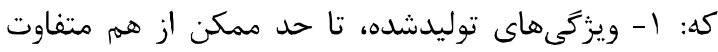
باشند. r- جدايىيذيرى بين طبقهها افزايش يابد. براى

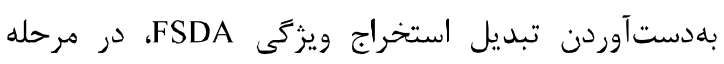
نخست بايد ويزّگىها را تا حد ممكن، متفاوت از هم استخراج و در مرحلهُ بعدى جدايىيذيرى طبقهها را بيشينه كنيه. به إنه

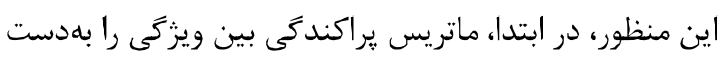

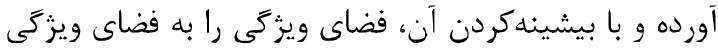

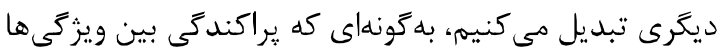

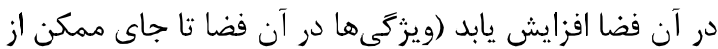

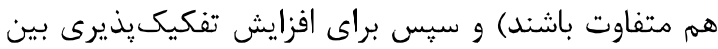

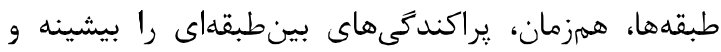

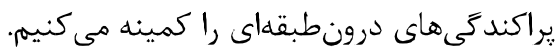

\section{צ-Y- استخراج ويثگى با استفاده از نمونههاى آموزشى وزندار (FEWT)}

در تعيين طبقه نمونهها همه ويزَّى ها نقش يكسانى ندارند. بلكه بعضى از ويزگى ها نقش عمدهترى در شناسايى طبقهها

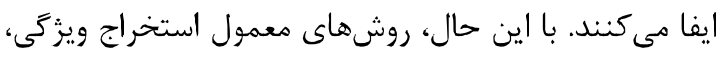

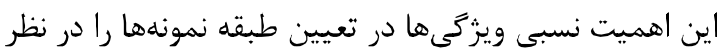
نمى

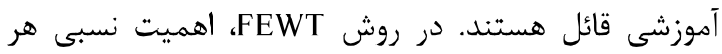

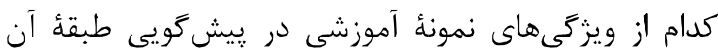

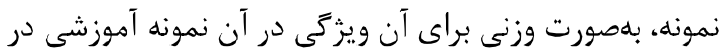

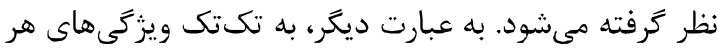

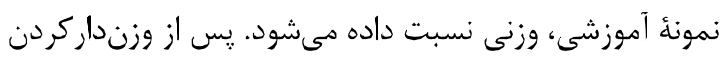

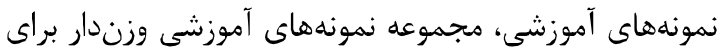

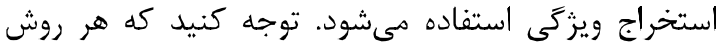

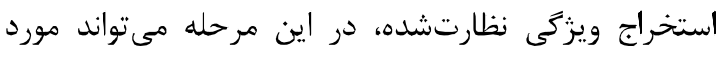

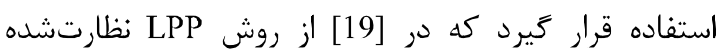
استفاده شده است. به عبارت ديخر براى توليد ماتريس شباهت 
روش استخراج ويزگى إن از تحليل مميز براى افرايش

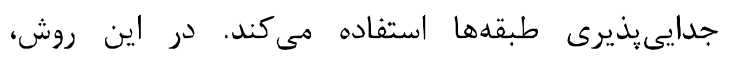

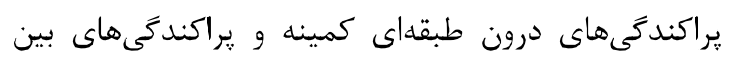

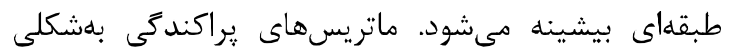

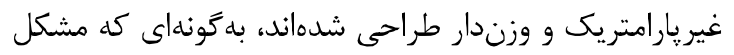

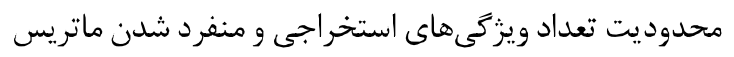

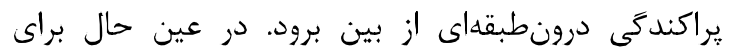
وزن دهى ماتر يسهاى ير اكندكى از مؤلفئ اصلى نخست (PC1)

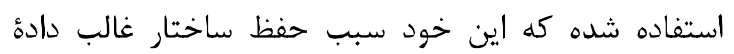

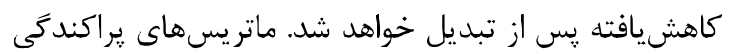
درونطبقاى و بينطبقهاى در روش ييشنهادى DA-PC1 بهصورت زير محاسبه مىشوند:

$$
\mathbf{S}_{w}=\sum_{j=1}^{n} \sum_{\substack{i=1 \\ l_{i}=l_{j}}}^{n} w_{i j}\left(\boldsymbol{x}_{t i}-\boldsymbol{x}_{t j}\right)\left(\boldsymbol{x}_{t i}-\boldsymbol{x}_{t j}\right)^{T}
$$

$\mathbf{S}_{b}=\sum_{j=1}^{n} \sum_{\substack{i=1 \\ l_{i} \neq l_{j}}}^{n} w_{i j}\left(\boldsymbol{x}_{t i}-\boldsymbol{x}_{t j}\right)\left(\boldsymbol{x}_{t i}-\boldsymbol{x}_{t j}\right)^{T}$

كه در روابط بالا، نمونهاى آموزشى است.

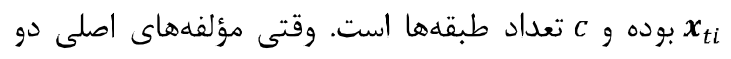

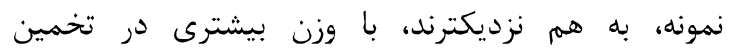

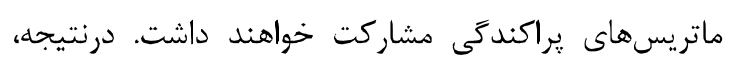

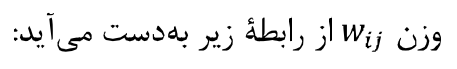

$w_{i j}=\frac{1}{\left|P C 1\left(x_{t i}\right)-P C 1\left(x_{t j}\right)\right|^{2}+1}$

عدد يك كه به مخرج اضافه شده، براى جلوگيرى از

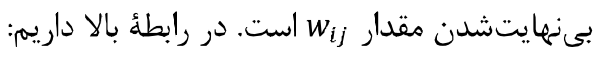

$$
\operatorname{PC} 1\left(\boldsymbol{x}_{t i}\right)=v_{1}^{T} x_{t i}
$$

PC1 $\left(x_{t i}\right)$

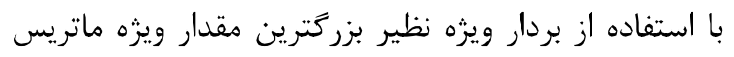
كواريانس دست مى آيد. همرجنين،

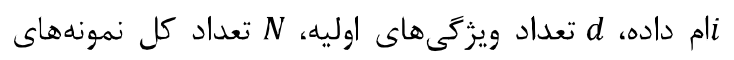
داده و ائ اين ترتيب، روش DA-PC1 علاوه بر اطلاعات جدايى يذيرى

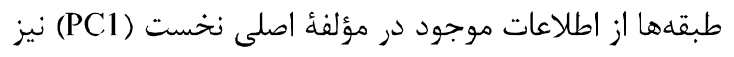

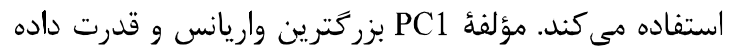

كه

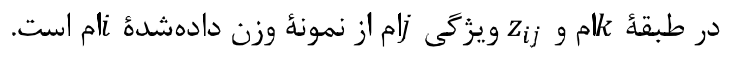

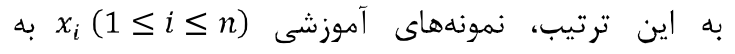

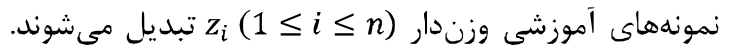

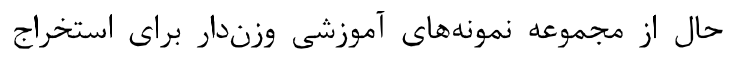

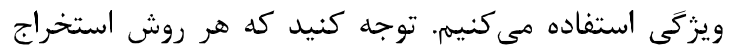

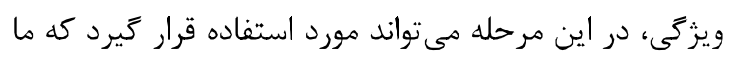

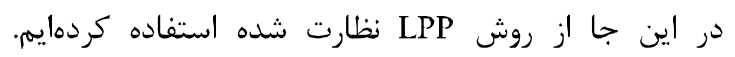

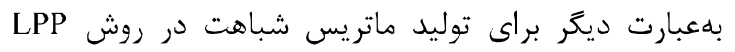
نظارتشده از نمونههاى آموزشى وزندار استفاده كردائ دايمه. با فرض اينكه كاهشيافته باشد، ماتريس تبديل A مسأله بهينهسازى زير بهدست مى آيد: $\min \left(\Phi=\sum_{i=1}^{n} \sum_{j=1}^{n}\left\|y_{i}-y_{j}\right\|^{2} s_{i j}\right)$ $s_{i j}=\left\{\begin{array}{rr}1 & z_{i}, z_{j} \text { belong to a class } \\ 0 & z_{i}, z_{j} \text { do not belong to a class }\end{array}\right.$ اكر براى دادة با بُعد بالا در فضاى اوليه و دادهُ با بُعد

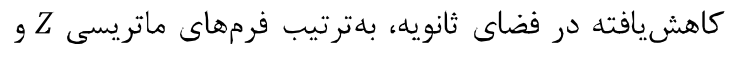
Y ا بهصورت زير در نظر بكيريم:

$Z=\left[z_{1}, z_{2}, \ldots, z_{n}\right]_{d \times n}$

$Y=\left[y_{1}, y_{2}, \ldots, y_{n}\right]_{d \times n}$ مىتوان تابع \$ را بهشكل ماتريسى بازنويسى كرد: $\Phi=\operatorname{tr}\left(Y L Y^{T}\right)$

$\min _{A}\left[\Phi=\operatorname{tr}\left(A Z L Z^{T} A^{T}\right)\right]$

كه در روابط بالا، شباهت است كه عناصر آن را

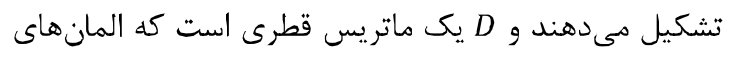
روى قطر آن، مجموع سطرى ماتريس S S است. براى استخراج

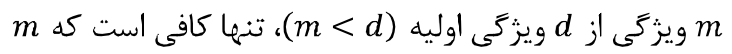

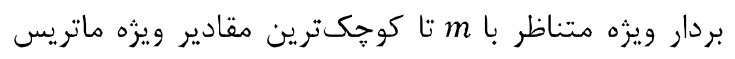
فاخ $2 L Z^{\mathrm{T}}$

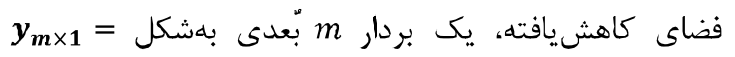
خواهد بود. $A_{m \times d} z_{d \times 1}$

(DA- تحليل مميز - مؤلفة اصلى نخست - Y-V PC1)

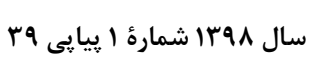


مىشود. NN يك طبقهبند ساده و غيريارامتريك است كه داراى دقت و كارايى خوبى براى طبقدبندى تصاوير جهره است. اين طبقلبند نياز به هيج تنظيمات خاصى ندارد و ساده و سريع اجرا مىشود. از آن جايى كه هدف ما در اين مقاله، مقايسه روشهاى استخراج ويزگى تصاوير جهره است، جهت إنى

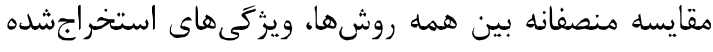

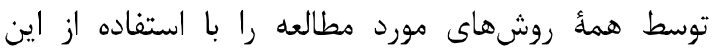
طبقلهبند، دستهبندى كرده و شناسايى تصاوير جهره را انجام مى دهيم. جهت مقايسه منصفانه لازم است كه از نمونههاى آموزشى يكسان و از طبقهبند يكسان با يارامترهاى يكسان استفاده شود كه اين امر در مقاله رعايت شده است. دقت شناسايى با استفاده از رابطؤ زير محاسبه شده است:

Recognition Accuracy $=$ (num_correct $)$ num_face) $\times 100$

در رابطهٔ بالا، num_face تعداد تصاوير جهره مورد آزمايش

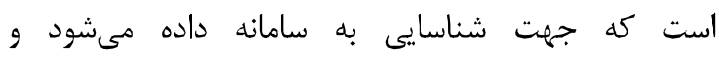
num_correct

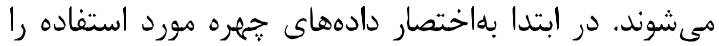

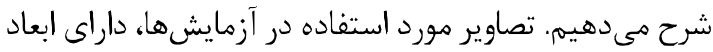


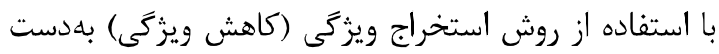

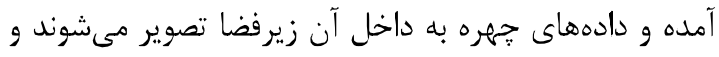
سيس از طبقلبند نزديكترين همسايكى (NN) با فاصله اقليدسى براى شناسايى جهره جديد (نمونه ازمون) استفاده

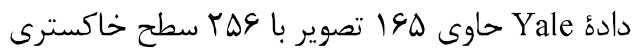

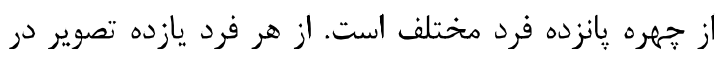

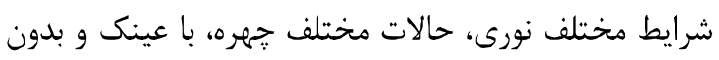
عينك اخذ شده است. دادة ORL حاوى جهارصد تصوير از جهره جهل فرد است. از هر فرد ده تصوير در زست و حالات

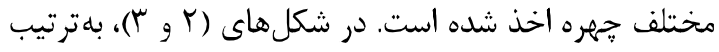

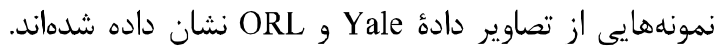

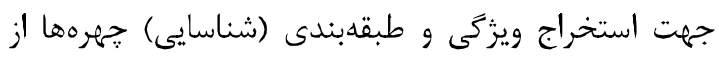

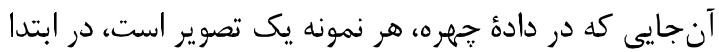

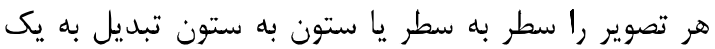

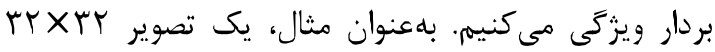

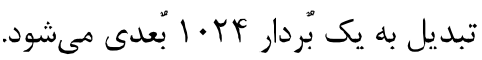

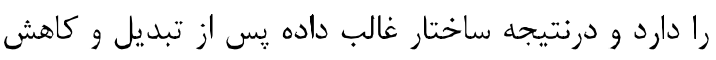
بّعد با استفاده از آن حفظ مى شوده. در بخش بعد، به آزمايش و ارزيابى روشهاى استخراج ادهاج ويزَى بالا بر روى دادهاى جهره مى يردازيم.

\section{ץ- اعمال روشهاى ييشنههادى استخراج ويزَّى بر روى دادهُ جهره}

در اين قسمت به بررسى روشهاى استخراج بيشنهادى خود رود

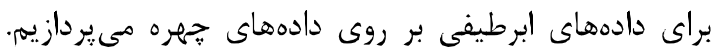

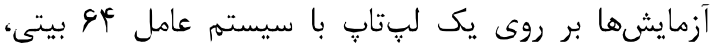

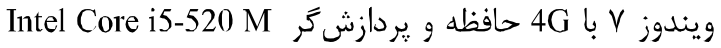
Processor $2.40 \mathrm{GHz}$ روشهاى شناسايى جهره از نرمافزار MATLAB نسخه

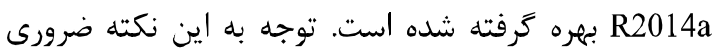
است كه ماهيت تصاوير ابرطيفى سنجش از دور با تصاوير קهره متفاوت است. تصاوير ابرطيفى، بلصورت يك مكعب

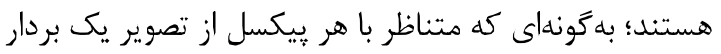

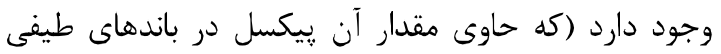

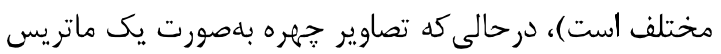
دوبعدى هستند؛ جايى كه بهازاى هر پيكسل از تصوير يك

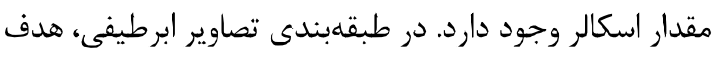

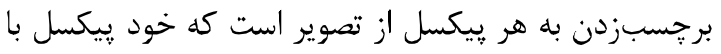

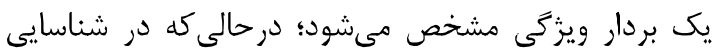
تصاوير קهره، هدف برجسبزدن به كل يك تصوير است؛ جايى كه با تغيير شكل ماتريس تصوير به يك بردار، كل تصوير

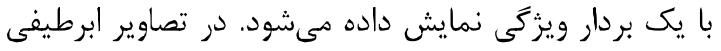

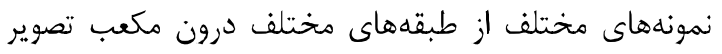

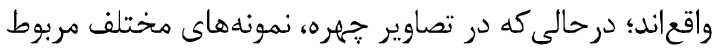
به طبقهها (افراد) مختلف، تصاوير مجزايى داخل ديتاست

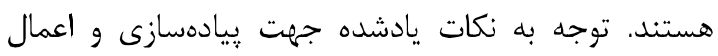

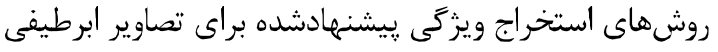

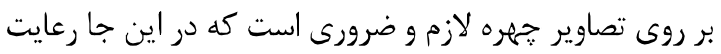

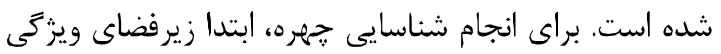
با استفاده از روش استخراج ويثگى (كاهش ويزَّى) بهدست

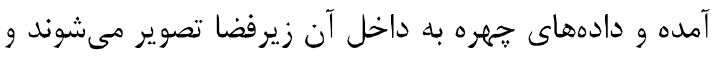

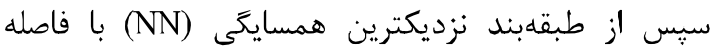
اقليدسى براى شناسايى جهره جديد (نمونه آزمايش) استفاده 


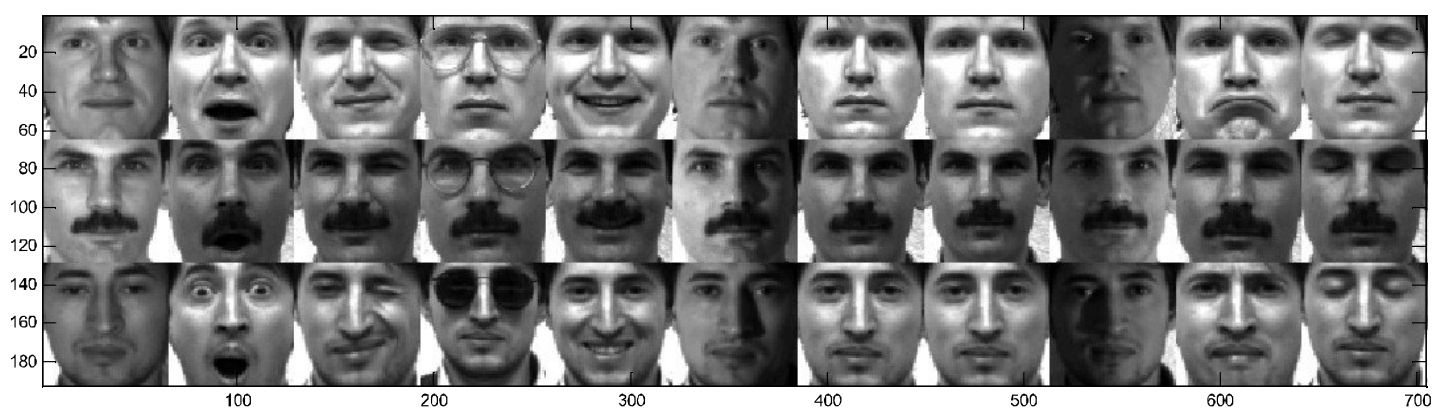

Yale شكل-Y)

(Figure-2): sample images of Yale dataset.

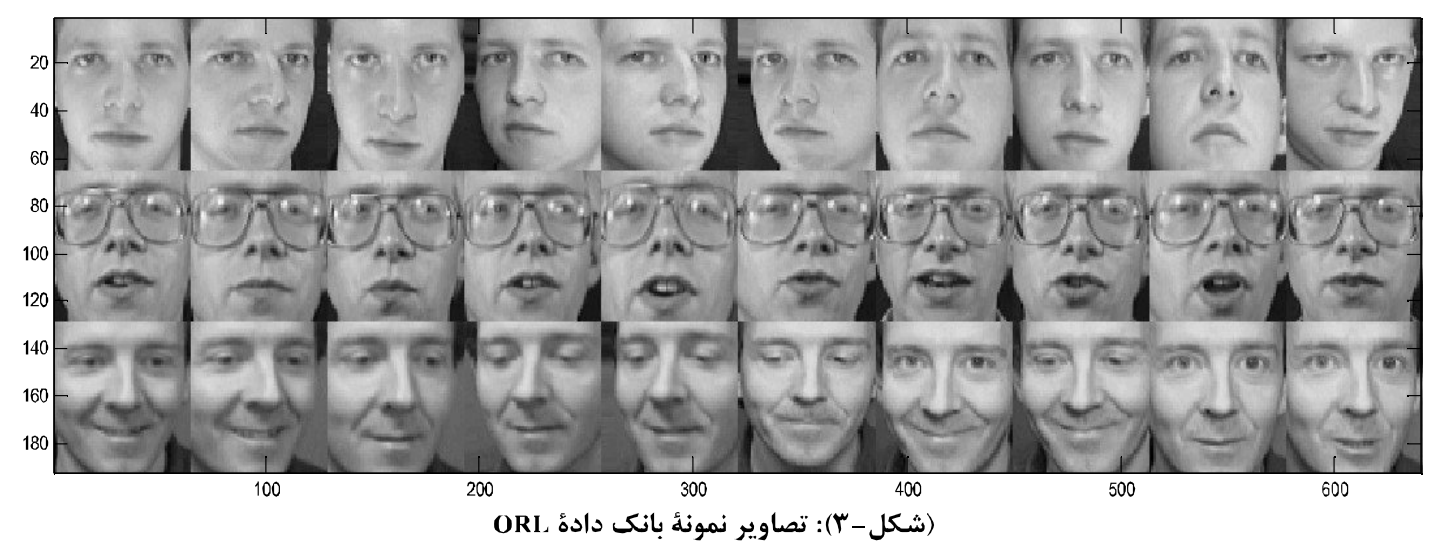

(Figure-3): sample images of ORL dataset.

مى آورند. روشهاى NSFE، FSDA CSLDA ، جزء اين دسته هستند شكل (Y) دستهبندى روشهاى روشاى ريشنهادى را نشان مى دهد. در شكلهاى (له تا م)، دقت شناسايى بهدست آمده در برابر

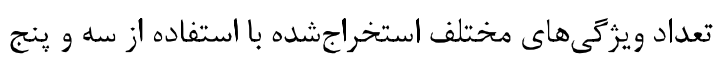

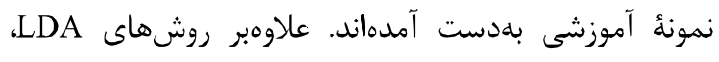

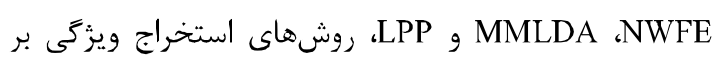

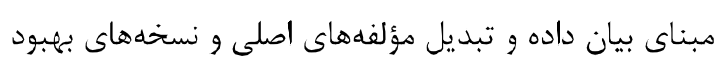

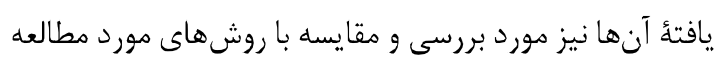

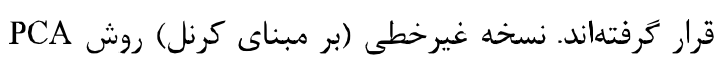

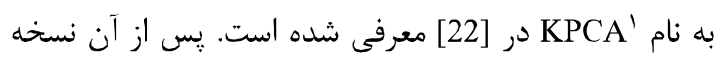

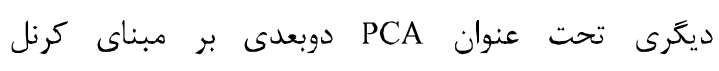

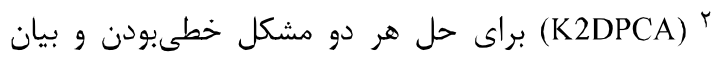

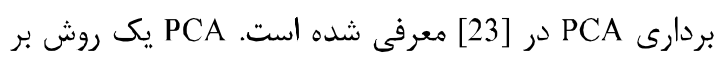

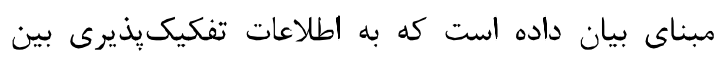

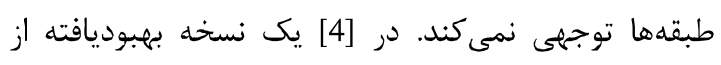

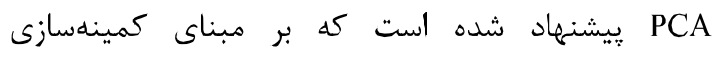

${ }^{1}$ Kernel based PCA (KPCA)

${ }^{2} \mathrm{kerncl}$ version of the 2DPCA method (K2DPCA)
ما در اينجا، هفت مورد از روشهاى يِيشنهادى

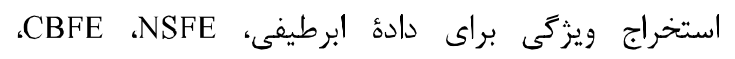

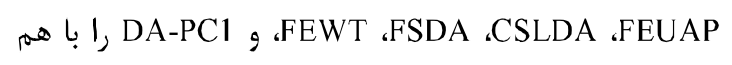
مقايسه كردايه. در روش FEUAPاز معيار فاصله براى تعيين نقاط جذب استفاده شده است. همرجنين :ههار روش استخراج

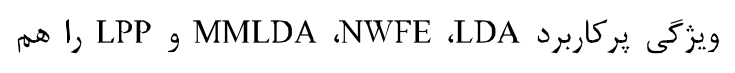
مورد آزمايش و مقايسه با روشهار برد جدائ جدايد قرار داديم.

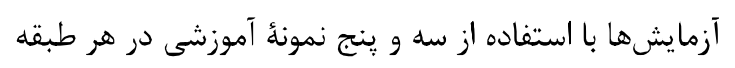
انجام شده است. هفت روش ييشنهادى استخراج ويزَّى را مى توان در

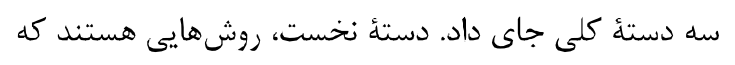

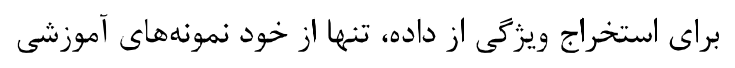

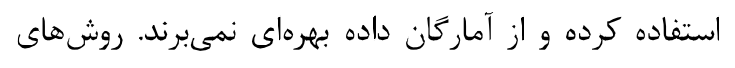

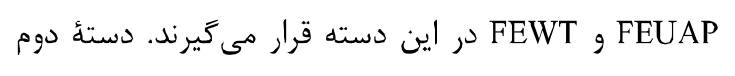

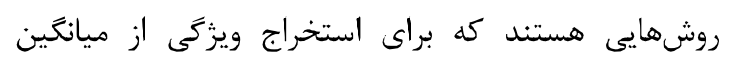

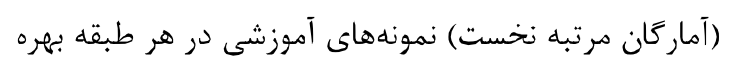

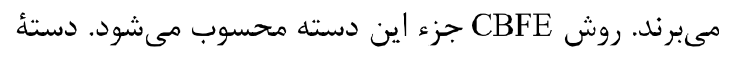

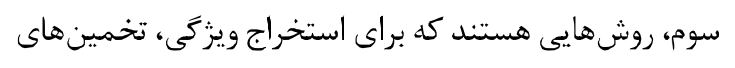

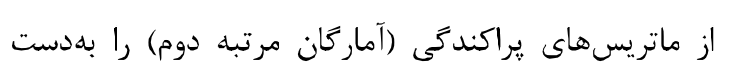




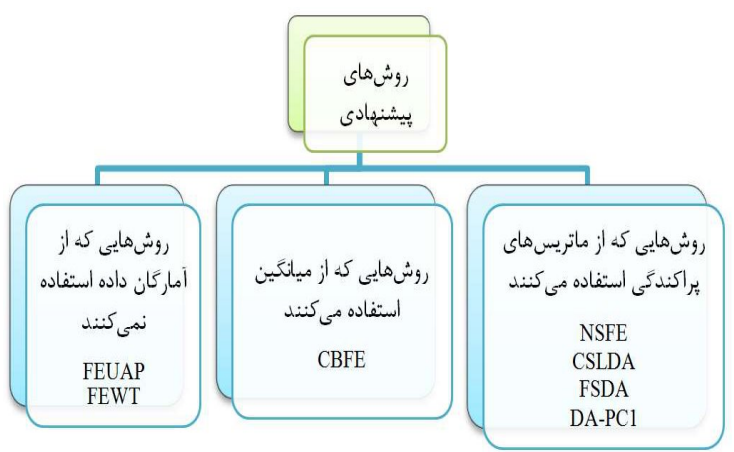

(شكل -F): دستدبندى روشهاى بييشنهادى استخراج ويزگى (Figure-4): Dividing the proposed feature extraction methods
يراكندگى هاى درونطبقهاى عمل مى كند. اين روش تحت عنوان PCA دوبعدى بر مبناى طبقئ '

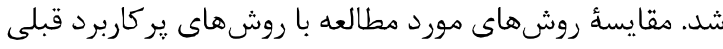
و همينطور روشهاى K2DPCA و K2DPCA KPCA جدول (1) نمايش داده شدهاند. بالاترين دقت شناسايى

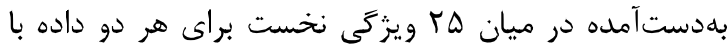
استفاده از سه و ينج نمونه آموزشى كزارش شدهاند. اعداد داخل يرانتز، تعداد ويزخىهايى هستند كه بهازاى آنها بالاترين دقت شناسايى بهدستآمده است. مقايسءٔ زمانى روش ها در شكل (9) مشاهده مىشود.

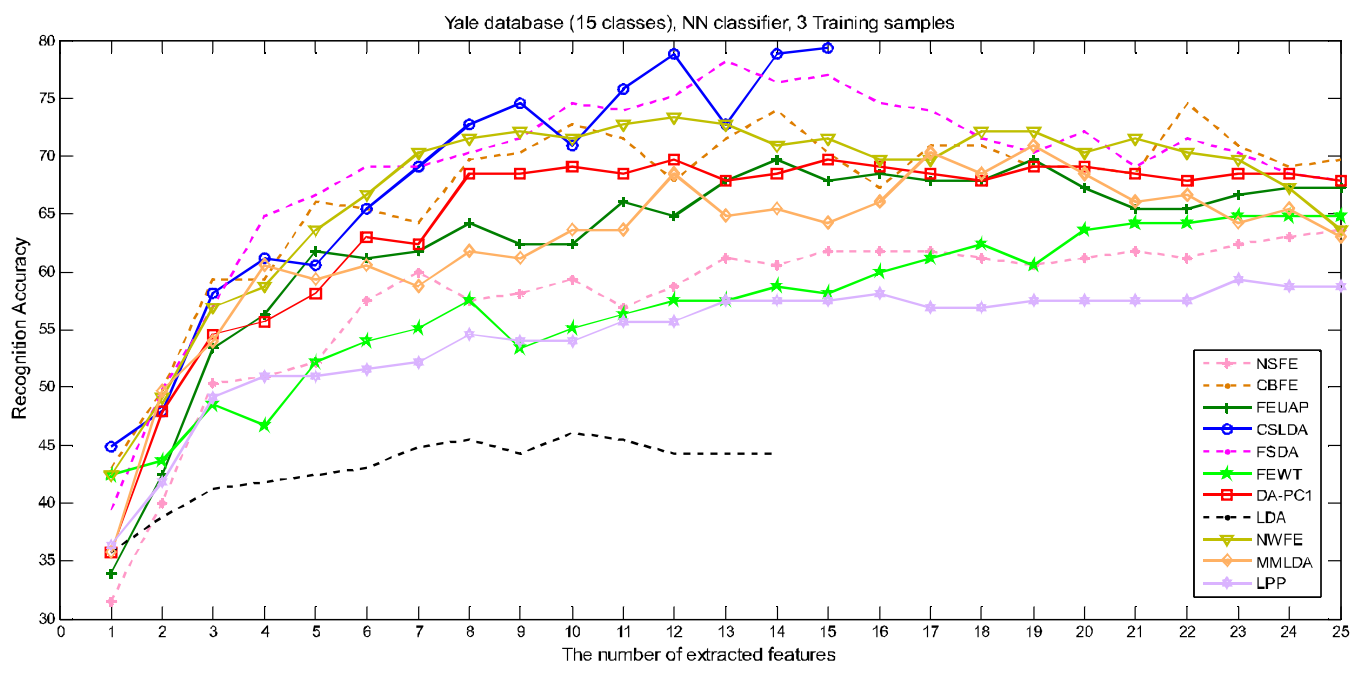

Yale (شكل -ه): دقت شناسايى در برابر تعداد ويزّى ها با سه نمونه آموزشى براي دادئ

(Figure-5): Recognition accuracy versus the number of features using 3 training samples for Yale dataset

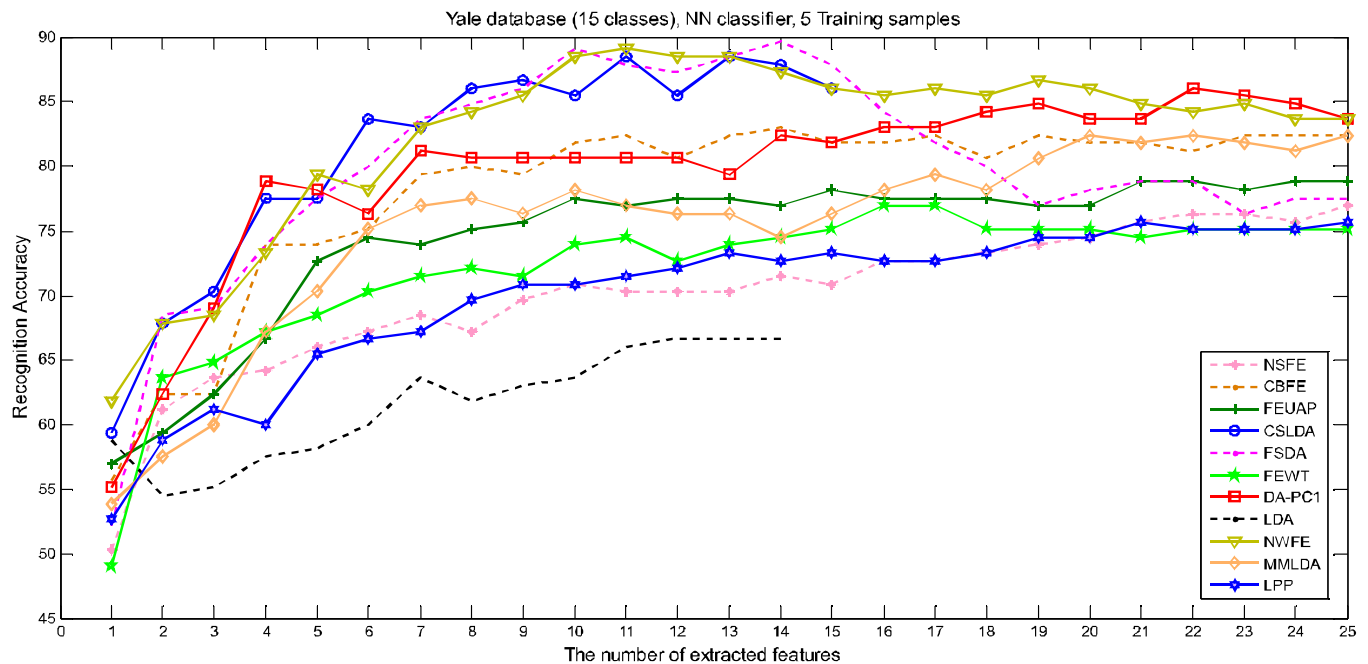

Yale شكل-9): دقت شناسايى در برابر تعداد ويثخى ها با ينج نمونه آموزشى براى دادهُ

(Figure-6): Recognition accuracy versus the number of features using 5 training samples for Yale dataset 


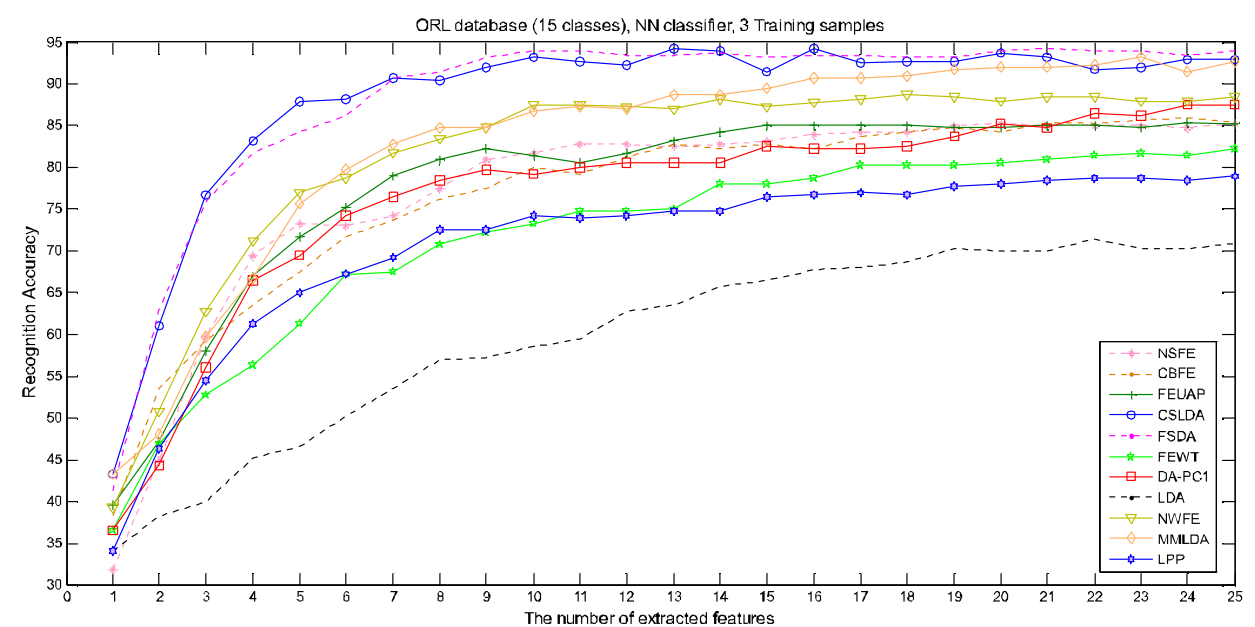

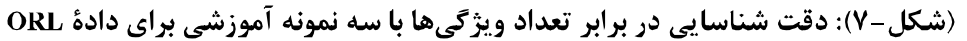

(Figure-7): Recognition accuracy versus the number of features using 3 training samples for ORL dataset

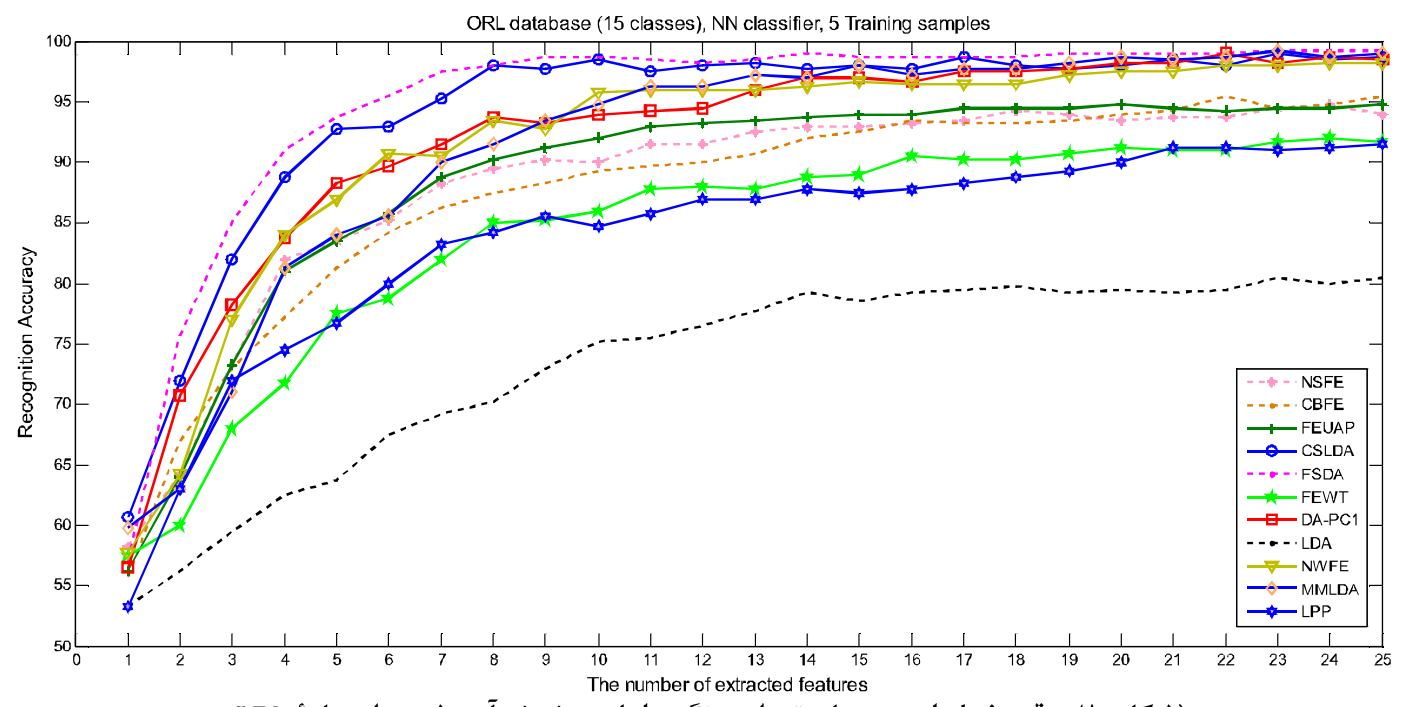

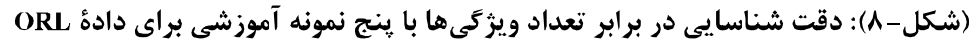

(Figure-8): Recognition accuracy versus the number of features using 5 training samples for ORL dataset

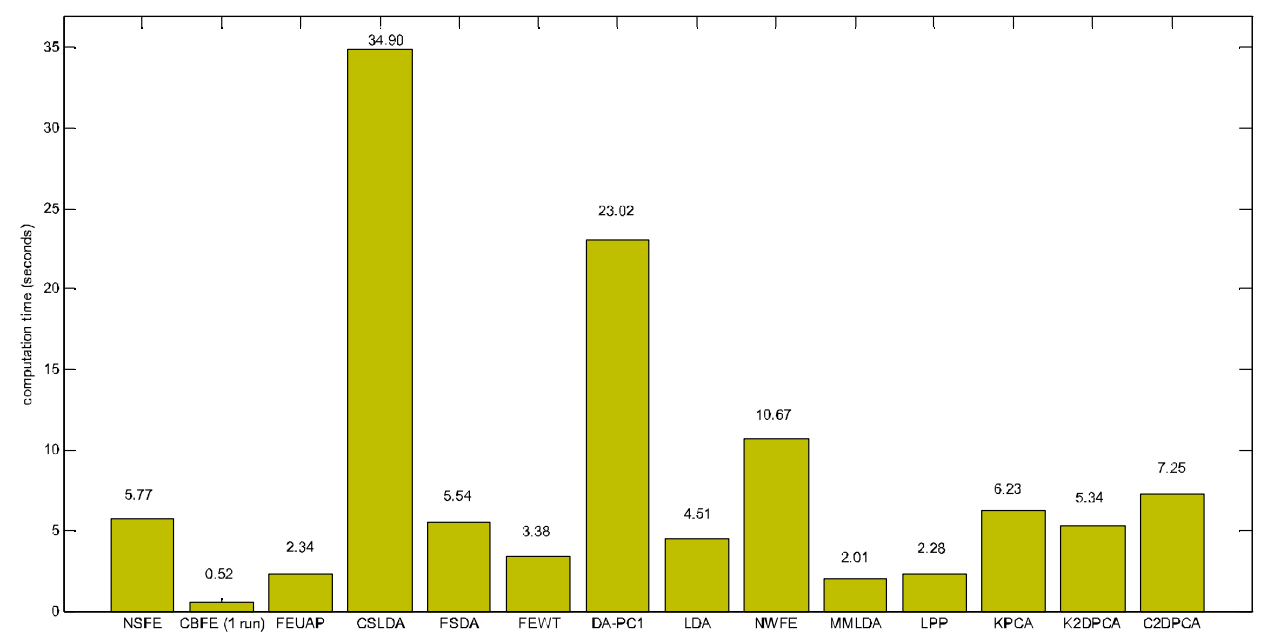

(شكل - 9): زمان محاسبات در فر آيندهاى استخراج ويزگى براى استخراج شش ويثخى از دادة Yale با استفاده از سه نمونهُ آموزشى

(Figure-9): Computation time in the feature extraction processes for extraction of 6 features using 3 training samples in Yale dataset 
(جدول-()): بالاترين دقت شناسايى (در ميان ها ويثَى نخست) بلدست آمده توسط روشهاى مختلف

(Table-1): The highest recognition accuracy (among the first 25 features) achieved by different methods

\begin{tabular}{|c|c|c|c|c|c|c|c|c|c|c|c|c|c|c|c|}
\hline Data & $\begin{array}{c}\text { No. } \\
\text { of } \\
\text { Trai } \\
\text { ning }\end{array}$ & NSFE & CBFE & $\begin{array}{c}\text { FEU } \\
\mathbf{A P}\end{array}$ & $\begin{array}{l}\text { CSL } \\
\text { DA }\end{array}$ & $\underset{\Lambda}{\text { FSD }}$ & $\begin{array}{c}\text { FEW } \\
\text { T }\end{array}$ & $\begin{array}{l}\text { DA- } \\
\text { PC1 }\end{array}$ & LDA & $\underset{\mathbf{E}}{\mathbf{N W F}}$ & $\begin{array}{l}\text { MM } \\
\text { LDA }\end{array}$ & LPP & $\underset{\boldsymbol{\Lambda}}{\mathbf{K P C}}$ & $\begin{array}{l}\text { K2D } \\
\text { PCA }\end{array}$ & $\begin{array}{l}\text { C2D } \\
\text { PCA }\end{array}$ \\
\hline \multirow{2}{*}{ Yale } & 3 & $\begin{array}{c}63.64 \\
(25)\end{array}$ & $\begin{array}{c}74.55 \\
(22)\end{array}$ & $\begin{array}{c}69.70 \\
(14)\end{array}$ & & $\begin{array}{c}78.18 \\
(13)\end{array}$ & $\begin{array}{c}64.85 \\
(23)\end{array}$ & $\begin{array}{c}69.70 \\
\text { (12) }\end{array}$ & $\begin{array}{c}46.06 \\
(10)\end{array}$ & $\begin{array}{c}73.33 \\
(12)\end{array}$ & $\begin{array}{c}70.91 \\
(19)\end{array}$ & $\begin{array}{c}59.39 \\
(23)\end{array}$ & $\begin{array}{c}72.13 \\
(8)\end{array}$ & $\begin{array}{c}75.54 \\
(7)\end{array}$ & $\begin{array}{c}78.87 \\
(6)\end{array}$ \\
\hline & 5 & $\begin{array}{c}76.97 \\
(25)\end{array}$ & $\begin{array}{c}83.03 \\
(14)\end{array}$ & $\begin{array}{c}78.79 \\
(21)\end{array}$ & $\begin{array}{c}88.48 \\
(11)\end{array}$ & $\begin{array}{c}89.70 \\
\text { (14) }\end{array}$ & $\begin{array}{c}76.97 \\
(16)\end{array}$ & $\begin{array}{c}86.06 \\
(22)\end{array}$ & $\begin{array}{c}66.67 \\
(12)\end{array}$ & $\begin{array}{c}89.09 \\
(11)\end{array}$ & $\begin{array}{c}82.42 \\
(20)\end{array}$ & $\begin{array}{c}75.76 \\
(21)\end{array}$ & $\begin{array}{c}79.44 \\
(10)\end{array}$ & $\begin{array}{c}83.45 \\
(9)\end{array}$ & $\begin{array}{c}88.93 \\
(9)\end{array}$ \\
\hline \multirow{2}{*}{ ORL } & 3 & $\begin{array}{c}85.25 \\
(20)\end{array}$ & $\begin{array}{c}86.00 \\
(24)\end{array}$ & $\begin{array}{c}85.50 \\
(24)\end{array}$ & $\begin{array}{c}94.25 \\
(13)\end{array}$ & $\begin{array}{c}94.25 \\
(21)\end{array}$ & $\begin{array}{c}82.25 \\
(25)\end{array}$ & $\begin{array}{c}87.50 \\
(24)\end{array}$ & $\begin{array}{c}71.50 \\
(22)\end{array}$ & $\begin{array}{c}88.75 \\
(18)\end{array}$ & $\begin{array}{c}93.25 \\
(23)\end{array}$ & $\begin{array}{l}79.00 \\
(25)\end{array}$ & $\begin{array}{c}89.26 \\
(13)\end{array}$ & $\begin{array}{c}90.23 \\
(11)\end{array}$ & $\begin{array}{c}93.03 \\
(10)\end{array}$ \\
\hline & 5 & $\begin{array}{c}94.75 \\
(24)\end{array}$ & $\begin{array}{c}95.50 \\
(22)\end{array}$ & $\begin{array}{c}94.75 \\
(20)\end{array}$ & $\begin{array}{c}99.00 \\
(23)\end{array}$ & $\begin{array}{c}99.25 \\
(23)\end{array}$ & $\begin{array}{c}92.00 \\
(24)\end{array}$ & $\begin{array}{c}99.00 \\
(22)\end{array}$ & $\begin{array}{c}80.50 \\
\text { (23) }\end{array}$ & $\begin{array}{c}98.25 \\
(24)\end{array}$ & $\begin{array}{c}99.25 \\
(23)\end{array}$ & $\begin{array}{c}91.50 \\
(25)\end{array}$ & $\begin{array}{c}93.22 \\
(16)\end{array}$ & $\begin{array}{c}94.45 \\
(12)\end{array}$ & $\begin{array}{c}97.54 \\
\text { (11) }\end{array}$ \\
\hline
\end{tabular}

كارايى كم LPP بلددليل اين است كه LPP از اطلاعات جدايى يذيرى طبقها براى تميز بين جهرهها استفاده نمى كند

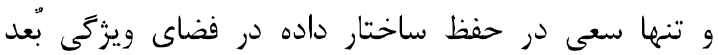
كاهش

مقايسة زمانى بين روشها نشان منان ميدهد كه بهترتيب و NWFE و مندترين روشها هستند. DA-PC1،CSLDA توجه كنيد كه زمان درجشده براى روش CBFE بهازاى يك بار اجراى الكوريتم kmeans است. با نكاهى اجمالى به نتايج دقت و سرعت در مىيابيم كه دركل، روشهاى دقيقتر، به بهان زمان محاسباتى بيشترى نياز دارند.

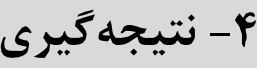

در اين مقاله، براى نخستينبار هفت روش استخراج ويثزى

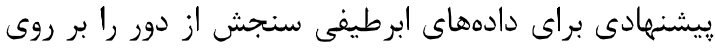

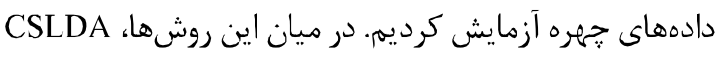

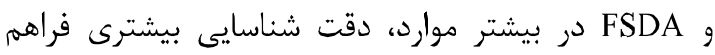

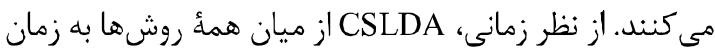
محاسباتى بيشترى نياز دارد. روش FSDA كه از دو معيار

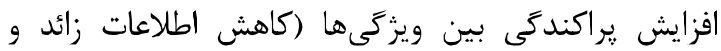

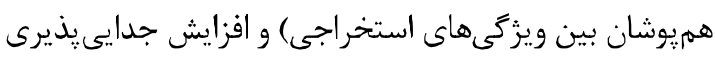

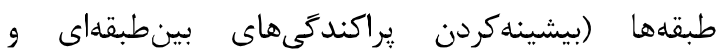
كمينهكردن يراكندگى هاى درونطبقهاى) بهطور همزمان بهره مىبرد، در كنار كارايى خوب، داراى زمان محاسباتى دانى

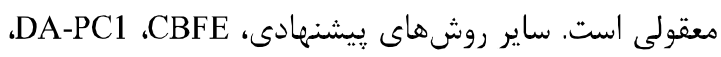
NSFE ،FEUAP روشهاى LPP نظارتشده و LDA داراى كارايى بهترى هستند و دو روش CBFE و DA-PC1 كاهى از دو دو روش قدرتمند NWFE و MMLDA نيز جلو مىزنئد.
نتايج آزمايشها نشان مىدهند بهطور كلى از ميان

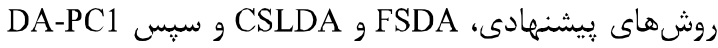

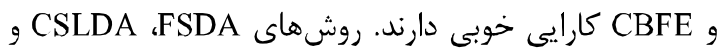

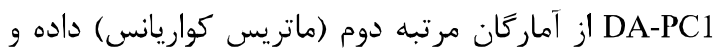
روش CBFE از آماركان مرتبه نخست دارنه داده (بردار ميانخًين)

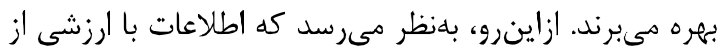

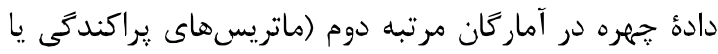

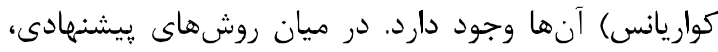
FEUAP و FEWT كه از آماركان داده استفاده نمى كنتند، نسبت به ساير روشهاى ييشنهادى ما داراى دقت كمترى

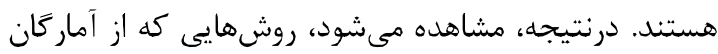

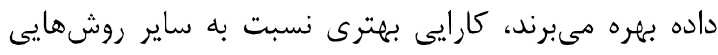

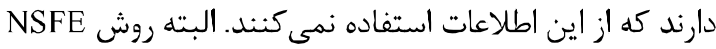

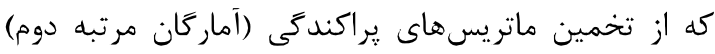

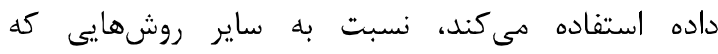

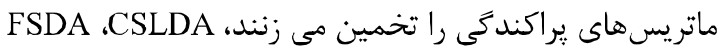
CSLDA كارايى كمترى دارد. برترى روش DA-PC1 , بهدليل استفاده از توانايى نمونههاى آزمايشى درى درى كنار

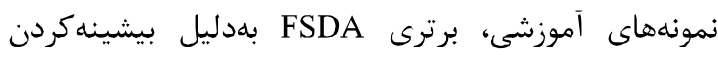

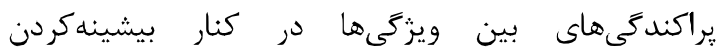
جدايى يذيرى طبقهها و برترى DA-PC1 بهدليل استفاده از

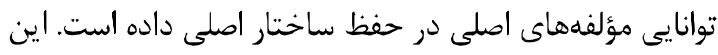

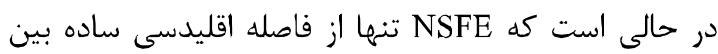

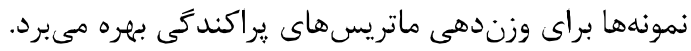
در ميان ساير روشهاى يركاربرد مورد بررسى نيز،

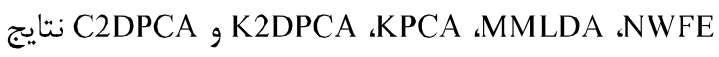
خوبى دارند و LDA و LPP بهترتيب داراى بدترين كارايى هستند. كارايى كم LDA بهدليل منفردشدن ماتريس يراكندگى درونطبقهاي با نمونههاى آموزشى كم است. 
[10] K. Fukunaga, Introduction to Statistical Pattern Recognition. San Diego, CA, USA: Academic, 1990.

[11] B.C. Kuo, D.A. Landgrebe, "Nonparametric weighted feature extraction for classification", IEEE Transactions on Geoscience and Remote Sensing, vol. 42, no. 5, pp. 1096-1105, 2004.

[12] J. Xu, J. Yang, Z. Gu, and N. Zhang, "Medianmean line based discriminant analysis", Neurocomputing, vol. 123, pp. 233-246, 2014.

[13] X.F.He, P.Niyogi, "Locality preserving projecttions", In: Advances in Neural Information Processing System, vol. 16, pp. 153-160, 2004.

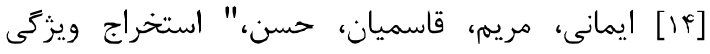

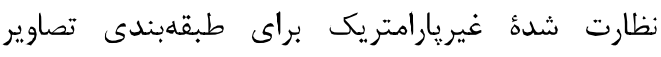

$$
\begin{aligned}
& \text { ابرطيفى با نمونذٔ آموزشى محدود"، فصلنامه صنايع برائ }
\end{aligned}
$$

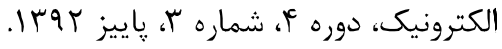

[14] M. Imani, H. Ghassemian, "Nonparametric Supervis Feature Extraction for Classification of Hyperspectral Images Using Limited Training Samples", Electronics Industries Quarterly, vol. 4, no.3, Autumn 2013.

[15] M. Imani, H. Ghassemian, "Band ClusteringBased Feature Extraction for Classification of Hyperspectral Images Using Limited Training Samples", IEEE Geoscience and Remote Sensing Letters, vol. 11, no. 8, pp. 1325-1329, 2014.

[16] M. Imani, H. Ghassemian, "Feature Extraction Using Attraction Points for Classification of Hyperspectral Images in a Small Sample Sizc Situation", IEEE Geoscience and Remote Sensing Letters, vol. 11, no. 11, pp. 1986-1990, 2014.

$$
\begin{aligned}
& \text { [IV] ايمانى، مريم، قاسميان، حسن،" طبقهبندى تصاوير } \\
& \text { ابرطيفى با استفاده از تحليل مميز خطى فضاى خوشه و }
\end{aligned}
$$

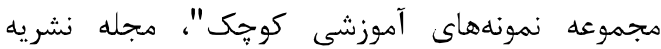

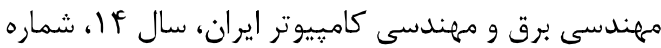

$$
\begin{aligned}
& \text { |، صفحات |1- }
\end{aligned}
$$

[17] M. Imani, H. Ghassemian, "Classification of Hyperspectral Images Using Cluster Space Linear Discriminant Analysis and Small Training Set", Iranian Journal of Electrical and Computer Engineering, vol. 14, no. 1, pp. 73-81, June 2016.

[18] M. Imani, H. Ghassemian, "Feature space discriminant analysis for hyperspectral data feature reduction", ISPRS Journal of Photogrammetry and Remote Sensing, vol. 102, pp. 113, 2015.

[19] M. Imani, H. Ghassemian, "Feature Extraction Using Weighted Training Samples", IEEE

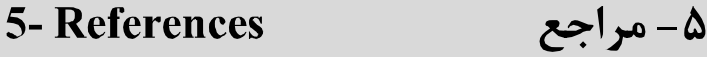

[1] P. Huang, C. Chen, Z. Tang, and Z. Yang, "Discriminant similarity and variance preserving projec-tion for feature extraction", Neurocomputing, vol. 139, pp. 180-188, 2014.

[2] S. Tan, X. Sun, W. Chan, L. Qu , and L. Shao, "Robust Face Recognition With Kernelized Locality-Sensitive Group Sparsity Representation", IEEE Transactions on Image Processing, vol. 26, no. 10, pp. 4661-4668, Oct. 2017.

[3] Y. Shen, M. Yang, B. Wei, C. T. Chou and W. Hu, "Learn to Recognise: Exploring Priors of Sparse Face Recognition on Smartphones", IEEE Transactions on Mobile Computing, vol. 16, no. 6, pp. 1705-1717, June 2017.

[4] C. Guzel Turhan and H. S. Bilge, "Class-wise twodimensional PCA method for face recognition", IET Computer Vision, vol. 11, no. 4, pp. 286-300, 2017.

[5] W. Wang, R. Wang, Z. Huang, S. Shan and X. Chen, "Discriminant Analysis on Riemannian Manifold of Gaussian Distributions for Face Recognition With Image Sets", IEEE Transactions on Image Processing, vol. 27, no. 1, pp. 151-163, Jan. 2018.

[6] Yang, W.-H., Dai, D.-Q., "Two-Dimensional Maximum Margin Feature Extraction for Face Recognition", IEEE Transactions on Systems, Man, and Cybernetics-Part B: Cybernetics, vol. 39, no. 4, pp. 1002-1012, 2009.

$$
\begin{aligned}
& \text { [V] [حمدخانى سميه، اديبى קيمان،" مدل تركيبى تحليل } \\
& \text { مؤلفه اصلى احتمالاتى بانظارت در خارجوب كاهش بعد }
\end{aligned}
$$

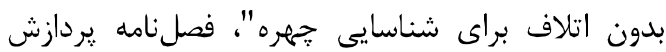

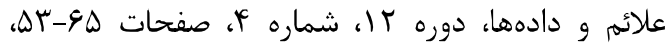

$$
\begin{aligned}
& \text {. rrat }
\end{aligned}
$$

[7] S. Ahmadkhani, P. Adibi, "Supervised Probabilistic Principal Component Analysis Mixture Model in a Lossless Dimensionality Reduction Framework for Face Recognition", Quarterly Journal of Signal and Data Processing, vol. 12, no. 4, pp. 53-65, 2016.

[8] Yang, M., Zhang, L., Shiu, S. C.-K., and Zhang, D., "Monogenic Binary Coding: An Efficient Local Feature Extraction Approach to Face Recognition", IEEE Transactions on Information Forensics and Security, vol. 7, no. 6, pp. 17381751, 2012.

[9] G. F. Hughes, "On the mean accuracy of statistical pattern recognition," IEEE Transactions on Information Theory, vol. IT-14, no. 1, pp. 55-63, 1968. 
Geoscience and Remote Sensing Letters, vol. 12, no. 7, pp. $1387-1386,2015$.

[20] M. Imani, H. Ghassemian, "Feature reduction of hyperspectral images: discriminant analysis and the first principal component", Journal of AI and Data Mining, vol. 3, no. 1, pp.1-9, 2015.

[21] G. H. Golub, and C. F.van Loan, Matrix Computations, 3rd ed. Baltimore, MD, USA: The Johns Hopkins Univ. Press, 1996.

[22] M. Yang, N. Ahuja, and D. Kriegman, "Face recognition using kernel eigenfaces", Proc. International Conference on Image processing, 2000, pp. 37-40.

[23] V. D. M Nhat, and S. Lee, "Kernel-based 2DPCA for Face Recognition", Proc. IEEE International Symposium on Signal Processing and Information Technology, December. 2007, pp. 35-39.

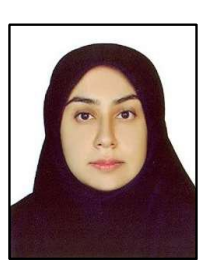

$$
\begin{aligned}
& \text { مريم ايمانى كارشناسى و كارشناسى } \\
& \text { ارشد خود را در رشته مهيندسى برق - ماتى } \\
& \text { گرايش مخابرات از دانشخًاه شاهد دريافت }
\end{aligned}
$$

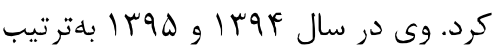

$$
\begin{aligned}
& \text { دوره دكتراو يسادكتراى خود را در دانشعاه }
\end{aligned}
$$

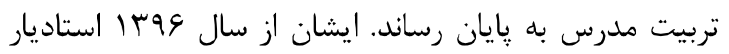

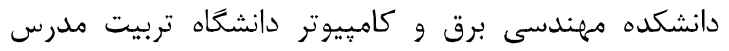

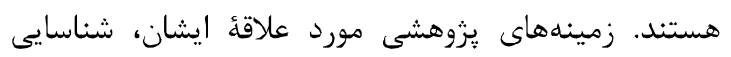

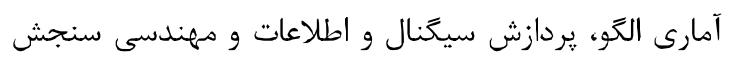

$$
\text { از دور است. }
$$

$$
\text { نشانى رايانامة ايشان عبارت است ازئ }
$$

\section{maryam.imani@modares.ac.ir}

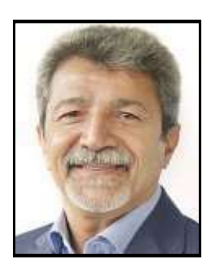

$$
\begin{aligned}
& \text { محمد حسن قاسميان يزدى تحصيلات }
\end{aligned}
$$

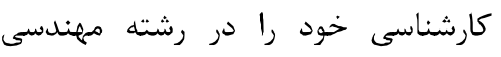

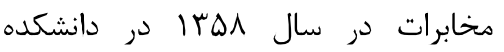

$$
\begin{aligned}
& \text { مخابرات تهران به يايان رساند. ايشان } \\
& \text { مدرك كارشناسى ارشد و دكتراى خود ران إنان }
\end{aligned}
$$

در رشتهُ مهندسى مخابرات در دانشگاه يردو آمريكا بهترتيب

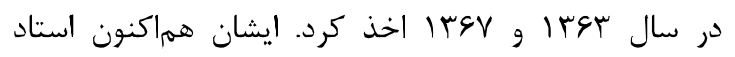
دانشكده مهندسى برق و كامييوتر هستند. آناليز و يردازش

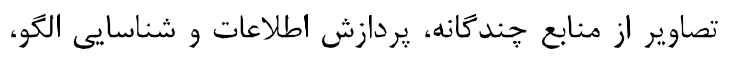

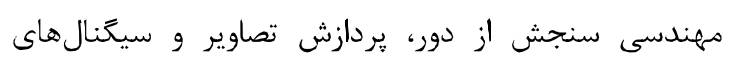
مهندسى يزشكى از جمله علاقههاى يثزوهشى ايشان است.

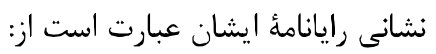
ghassemi@modares.ac.ir 
